\title{
Caracterização de isolados de Colletotrichum spp. associados às frutíferas no Estado de São Paulo
}

\author{
Hugo José Tozze Júnior ${ }^{1}$, Ana Carolina Firmino², Ivan Herman Fischer ${ }^{3}$, Edson Luiz Furtado ${ }^{4}$, Nelson Sidnei Massola \\ Júnior $^{1}$
}

\begin{abstract}
${ }^{1}$ Escola Superior de Agricultura "Luiz de Queiroz”, Universidade de São Paulo, Av. Pádua Dias, CP.09, CEP 13418-900, Piracicaba, São Paulo. ${ }^{2}$ Faculdade de Ciências Agrárias e Tecnológicas, Universidade Estadual Paulista Júlio de Mesquita Filho, Rodovia Comandante João Ribeiro de Barros, Km. 651, CEP 17900-000, Dracena, São Paulo. ${ }^{3}$ Agência Paulista de Tecnologia dos Agronegócios, Pólo de Desenvolvimento Tecnológico dos Agronegócios do Centro Oeste, Av. Rodrigues Alves, n. 40, CEP 17030-000, Bauru, São Paulo. ${ }^{4}$ Faculdade de Ciências Agronômicas, Universidade Estadual Paulista Júlio de Mesquita Filho, Rua José Barbosa de Barros, n.1780, CEP 18610-307, Botucatu, São Paulo.
\end{abstract}

Autor para correspondência: Hugo José Tozze Junior (htozze@gmail.com)

Data de chegada: 29/07/2014. Aceito para publicação em: 14/07/2015.

$10.1590 / 0100-5405 / 2021$

\section{RESUMO}

Tozze Júnior, H.J.; Firmino, A.C.; Fischer, I.H.; Furtado, E.L.; Massola Júnior, N.S. Caracterização de isolados de Colletotrichum spp. associados às frutíferas no Estado de São Paulo. Summa Phytopathologica, v.41, n.4, p.270-280, 2015.

O Estado de São Paulo é um dos maiores produtores de frutas no Brasil. A competitividade no comércio internacional de frutas demanda a minimização de danos pós-colheita, especialmente os causados pela antracnose. Para o controle eficaz da antracnose em uma região é necessário conhecer quais espécies estão associadas a cada hospedeiro e qual a variabilidade dos agentes causais. Este trabalho objetivou caracterizar e identificar isolados de Colletotrichum de frutíferas cultivadas no Estado de São Paulo, Brasil. Foram analisados 93 isolados obtidos de abacate, manga, maracujá e pêssego, por meio de morfometria de conídios e colônias e análise molecular (amplificação por PCR com oligonucleotídeos espécie-específicos e análise de sequências de nucleotídeos das regiões ITS e $\beta$-tubulina). Alta variabilidade morfométrica foi observada entre os isolados. A análise molecular indicou que, no Estado de São Paulo, as antracnoses do abacate, manga, maracujá e pêssego podem ser causadas por diferentes espécies do complexo C. gloeosporoides, revelando também a presença de $C$. boninense associada à antracnose do maracujá e de espécies não identificadas dos complexos C. acutatum e C. gloeosporioides causando antracnose em pêssego.

Palavras-chave: Pós-colheita; Antracnose; Abacate; Manga; Maracujá; Pêssego.

ABSTRACT

Tozze Júnior, H.J.; Firmino, A.C.; Fischer, I.H.; Furtado, E.L.; Massola Júnior, N.S. Characterization of Colletotrichum spp. isolates associated with fruit trees in the state of São Paulo. Summa Phytopathologica, v.41, n.4, p.270-280, 2015.

The state of São Paulo is one of the largest fruit producers in Brazil. Competitiveness in the international trade in fruits has demanded the minimization of postharvest damage, especially that caused by anthracnose. For the effective control of anthracnose in a certain region, it is necessary to know which species are associated with each host and the variability of the causal agents. This study aimed to characterize and identify Colletotrichum isolates from fruit trees grown in the state of São Paulo, Brazil. A total of 93 isolates obtained from avocado, mango, passion fruit and peach were analyzed according to conidium and colony morphology and molecular analysis (PCR amplification with species-specific primers and analysis of nucleotide sequences of the ITS regions and $\beta$-tubulin). There was high morphometric variability among isolates. Molecular analysis indicated that, in the state of São Paulo, anthracnose of avocado, mango, passion fruit and peach can be caused by different species of the $C$. gloeosporoides complex, also revealing the presence of $C$. boninense associated with passion fruit anthracnose and unidentified species of $C$. acutatum and $C$. gloeosporioides complexes causing anthracnose in peach.

Additional key-words: Postharvest; anthracnose; avocado; mango; passion fruit; peach.

O gênero Colletotrichum, responsável por doenças conhecidas como antracnoses, é considerado um dos mais importantes grupos de fungos fitopatogênicos do mundo (10). Esses fungos estão distribuídos principalmente em regiões tropicais e subtropicais e afetam especialmente a produção de frutas (8). A antracnose é freqüentemente causada por mais de uma espécie de Colletotrichum. O abacateiro, por exemplo, pode ser infectado por C. gloeosporioides (Penz.) Penz. \& Sacc., C. acutatum J.H. Simmonds e por $C$. boninense Moriwaki, Toy. Sato \& Tsukib. $(5,23)$ que também causam antracnose em maracujá $(3,14,27)$. Por sua vez, a manga e o pêssego são hospedeiros tanto de C. gloeosporioides como de C. acutatum $(1,2,6,12,16,22)$.

A ocorrência de duas ou mais espécies de Colletotrichum parasitando um mesmo hospedeiro dificulta o controle da antracnose. Este fato se deve ao comportamento diferenciado entre espécies, como já foi verificado para a antracnose do pimentão no Brasil, que pode ser causada por cinco espécies distintas de Colletotrichum com reações diferentes aos fungicidas utilizados no seu controle (26). Desta forma, 
para cada doença, é importante conhecer quais espécies do agente causal ocorrem, quais predominam, e qual a variabilidade intra e inter-específica do patógeno, regionalmente.

Os estudos de caracterização baseados na integração de métodos são fundamentais para que se identifique corretamente e se conheça a amplitude da variabilidade existente entre isolados de um determinado patógeno, fornecendo subsídios para o desenvolvimento de medidas de controle eficazes da doença (7).

Este trabalho objetivou caracterizar e identificar isolados de Colletotrichum causadores de antracnose em frutíferas no Estado de São Paulo.

\section{MATERIAL E MÉTODOS}

\section{Isolados utilizados}

Utilizaram-se 93 isolados monospóricos de Colletotrichum spp. obtidos de abacate, manga, maracujá e pêssego coletados no Estado de São Paulo (Tabela 1). Todos os isolados tiveram a patogenicidade confirmada no hospedeiro de origem por meio de inoculações segundo Cai et al. (7), reproduzindo sintomas típicos da antracnose.

\section{Caracterização morfo-cultural}

Discos de BDA Acumedia ${ }^{\circledR}$ com 6 mm de diâmetro, contendo estruturas do fungo, foram retirados das bordas de colônias com 5 dias de cada isolado e transferidos para o centro de placas de Petri contendo o mesmo tipo de meio. Após a transferência, os isolados foram incubados nas temperaturas de $15,20,25,30$ e $35 \pm 1^{\circ} \mathrm{C}$, sob fotoperíodo de 12 horas, por cinco dias. Diariamente mensuraramse diâmetros perpendiculares das colônias com paquímetro. A velocidade média de crescimento da colônia, expressa em milímetros por dia, foi utilizada para as análises estatísticas. Após cinco dias de cultivo, avaliou-se a coloração da colônia e a presença de escleródios, setas e massa de esporos. O experimento foi conduzido em delineamento inteiramente casualizado, com quatro repetições por tratamento, sendo cada parcela experimental composta por uma placa. Os dados correspondentes à velocidade de crescimento da colônia dos isolados foram submetidos à análise de variância e as médias foram comparadas por meio do teste de Scott-Knott ao nível de $5 \%$ de probabilidade, utilizando-se o programa Sisvar (UFLA, Lavras).

A caracterização morfológica foi realizada com lâminas semi-permanentes, preparadas com lactofenol, contendo conídios obtidos de colônias de cada isolado, cultivadas em meio de aveia (40 g de aveia, $15 \mathrm{~g}$ de agar, $1 \mathrm{~L}$ de água destilada) por 7 dias, sob luz constante e temperatura de $25 \pm 1{ }^{\circ} \mathrm{C}$. Cem conídios de cada isolado foram classificados de acordo com os seguintes formatos: (1) fusiforme, com ápices afilados; (2) oblongo, com ápices arredondados; (3) clavado, afilado em uma extremidade e oblongo na outra; (4) oblongo com constrição na região mediana (28).O comprimento, largura e relação entre o comprimento e a largura dos conídios, foram determinados pela mensuração de 50 conídios de cada isolado. Para as análises morfológicas foi utilizado sistema de vídeo-câmara instalado em microscópio óptico Opton ${ }^{\circledR}$, modelo TA-0124XS. A imagem foi transmitida para computador e analisada por meio do programa EDN-2, previamente calibrado com a utilização de lâmina micrométrica. Os resultados da morfometria foram submetidos à análise de variância e as médias comparadas por meio do teste de Scott-knott ao nível de 5\% de probabilidade, utilizando-se o programa Sisvar (UFLA, Lavras).

\section{Caracterização molecular}

A extração de DNA foi realizada conforme o método desenvolvido por Murray \&Thompson (17). O DNA obtido foi quantificado em GenQuant (Pharmacia, Biotech, San Francisco, CA, EUA), à razão A260nm/A280nm e as suspensões diluídas até a concentração de $10 \mathrm{ng}$ DNA $/ \mu \mathrm{L}$. A reação de polimerase em cadeia para identificação do gênero Colletotrichum foi realizada com os oligonucleotídeos Cc1F1 (5'-ACC TAA CTG TTG CTT CGG CG-3') e Cc2R1 (5'-AAA TTT GGG GGT TTT ACG GC-3'), de acordo com Cullen et al. (9). Para identificação do complexo C. acutatum utilizaram-se os oligonucleotídeos CaInt2 (5'-GGG GAA GCC TCT CGC GG-3') e ITS4 (5'- TCC TCC GCT TAT TGA TAT GC-3'), conforme Sreenivasaprasad et al. (24). A identificação do complexo $C$. gloeosporioides foi realizada pelos oligonucleotídeos CgInt (5'-GGC CTC CCG CCT CCG GGC GG-3') e ITS4 segundo Mills et al. (16). Os oligonucleotídeos Col1 (5'-GCC GTC CCC TGA AAA G-3') e ITS4, desenvolvidos para uma espécie de Colletotrichum não identificada que ocorre em algumas frutíferas na Colômbia e que amplificaram fragmentos de DNA de isolados do complexo C. boninense no trabalho de Pileggi et al. (20) foi utilizado de acordo com Afanador-Kafuri et al. (2). Após a amplificação, os produtos das PCRs foram aplicados em gel de agarose $1 \%$ contendo $0,5 \mu \mathrm{L} / \mathrm{mL}$ de brometo de etídio. A corrida eletroforética foi realizada em corrente constante de 5 volts/cm por $1 \mathrm{~h}$. As bandas de DNA foram visualizadas em transiluminador de ultravioleta e fotografadas. Todas as análises foram realizadas utilizando-se amostras de DNA de isolados padrões das espécies C. acutatum (TUT-137), C. gloeosporioides (AVO-33-4B) e Colletotrichum sp. (Man-76), o qual reage com os oligonucleotídeos Coll/ITS4 (2).

Para a análise das sequências de nucleotídeos, isolados representativos dos hospedeiros estudados tiveram a região ITS-5.8S rDNA amplificada com os pares de oligonucleotídeos ITS 1 (5' TCC GTA GGT GAA CCT GCG G 3') e ITS 4, que geram um fragmento de aproximadamente $600 \mathrm{pb}$ (29). A região do gene da $\beta$-tubulina foi amplificada com os oligonucleotídeos Bt2-F (5'GGT AAC CAA ATC GGT GCT GCT TTC 3') e Bt2-R (5'ACC CTC AGT GTA GTG ACC CTT GGC 3'), gerando um fragmento de aproximadamente $500 \mathrm{pb}$ (13). Para sequenciamento dos fragmentos amplificados, $100 \mu \mathrm{L}$ do produto de PCR foi purificado com o Kit SV Gel and PCR Clean UP system $\left(\right.$ Promega $^{\circledR}$ ). O sequenciamento foi realizado pela empresa Macrogen, Seul, Coréia do Sul, utilizando-se o kit BigDye ${ }^{\circledR}$ terminator v3.1 cycle sequencing, em sequenciador automático ABI 3730 XL (Applied Biosystems). As sequências obtidas foram editadas usando o programa BioEdit Sequence Alignment Editor (1997-2005), concatenadas com o auxílio do programa Mega 5.05 e alinhadas pelo Clustal W. A árvore filogenética foi construída pelo programa Mega 5.05 usando o modelo de comparação Neighbor-Joining com o método "p-distance" (18). A consistência dos agrupamentos foi verificada com bootstrap de 10.000 replicações. Sequências de isolados pertencentes a diferentes espécies foram obtidas do GenBank e utilizadas na análise (Tabela 2).

\section{RESULTADO E DISCUSSÃO}

\section{Caracterização morfo-cultural}

As colônias, após cinco dias de cultivo à $25^{\circ} \mathrm{C}$ sob fotoperíodo de 12 horas, apresentaram crescimento denso e cotonoso. Para $60,2 \%$ dos isolados o micélio demonstrou-se predominantemente brancoacizentado, enquanto os demais isolados produziram colônias com micélio cinza (Figura 1). O reverso da colônia foi predominantemente castanho para $86,0 \%$ dos isolados, salmão para $12,9 \%$ dos isolados e 
Tabela 1. Denominação, hospedeiro, município de origem e ano de coleta de isolados de Colletotrichum spp. obtidos de frutos com sintomas de antracnose.

\begin{tabular}{|c|c|c|c|}
\hline Denominação & Hospedeiro & Município de origem & Ano de Coleta \\
\hline AV-01 & Abacate & Itapetininga, SP & 2008 \\
\hline AV-02 & Abacate & Itapetininga, SP & 2008 \\
\hline AV-03 & Abacate & Olímpia, SP & 2008 \\
\hline AV-04 & Abacate & Piracicaba, SP & 2008 \\
\hline AV-05 & Abacate & Bauru, SP & 2008 \\
\hline AV-06 & Abacate & Bauru, SP & 2008 \\
\hline AV-07 & Abacate & Limeira, SP & 2008 \\
\hline AV-08 & Abacate & Piracicaba, SP & 2008 \\
\hline AV-09 & Abacate & Olímpia, SP & 2008 \\
\hline AV-10 & Abacate & Bernardino de Campos, SP & 2008 \\
\hline AV-11 & Abacate & Bauru, SP & 2008 \\
\hline AV-12 & Abacate & Limeira, SP & 2008 \\
\hline AV-13 & Abacate & Bernardino de Campos, SP & 2008 \\
\hline AV-14 & Abacate & Bauru, SP & 2008 \\
\hline AV-15 & Abacate & Dois Córregos, SP & 2008 \\
\hline AV-16 & Abacate & Itapetininga, SP & 2008 \\
\hline AV-17 & Abacate & Piracicaba, SP & 2008 \\
\hline AV-18 & Abacate & Piracicaba, SP & 2008 \\
\hline AV-19 & Abacate & Olímpia, SP & 2008 \\
\hline AV-20 & Abacate & Jardinópolis, SP & 2008 \\
\hline AV-21 & Abacate & Dois Córregos, SP & 2008 \\
\hline AV-22 & Abacate & Bernardino de Campos, SP & 2008 \\
\hline AV-23 & Abacate & Limeira, SP & 2008 \\
\hline $\mathrm{AV}-24$ & Abacate & Bernardino de Campos, SP & 2008 \\
\hline AV-25 & Abacate & Bernardino de Campos, SP & 2008 \\
\hline AV-26 & Abacate & Dois Córregos, SP & 2008 \\
\hline AV-27 & Abacate & Jardinópolis, SP & 2008 \\
\hline AV-28 & Abacate & Olímpia, SP & 2008 \\
\hline AV-29 & Abacate & Itapetininga, SP & 2008 \\
\hline AV-30 & Abacate & Jardinópolis, SP & 2008 \\
\hline $\mathrm{MN}-31$ & Manga & Jaboticabal, SP & 2009 \\
\hline $\mathrm{MN}-32$ & Manga & Bauru, SP & 2009 \\
\hline $\mathrm{MN}-33$ & Manga & Cabrália Paulista, SP & 2009 \\
\hline $\mathrm{MN}-34$ & Manga & Monte Alto, SP & 2009 \\
\hline $\mathrm{MN}-35$ & Manga & Magda, SP & 2009 \\
\hline $\mathrm{MN}-36$ & Manga & São José do Rio Preto, SP & 2009 \\
\hline $\mathrm{MN}-37$ & Manga & Borborema, SP & 2009 \\
\hline $\mathrm{MN}-38$ & Manga & Bauru, SP & 2009 \\
\hline MN-39 & Manga & Monte Alto, SP & 2009 \\
\hline $\mathrm{MN}-40$ & Manga & Cabrália Paulista, SP & 2009 \\
\hline $\mathrm{MN}-41$ & Manga & Magda, SP & 2009 \\
\hline $\mathrm{MN}-42$ & Manga & Jaú, SP & 2009 \\
\hline $\mathrm{MN}-43$ & Manga & Borborema, SP & 2009 \\
\hline $\mathrm{MN}-45$ & Manga & Catanduva, SP & 2009 \\
\hline $\mathrm{MN}-46$ & Manga & Monte Alto, SP & 2009 \\
\hline $\mathrm{MN}-47$ & Manga & São José do Rio Preto, SP & 2009 \\
\hline $\mathrm{MN}-48$ & Manga & Jaú, SP & 2009 \\
\hline
\end{tabular}

\begin{tabular}{|c|c|c|c|}
\hline Denominação & Hospedeiro & Município de origem & Ano de Coleta \\
\hline MN-49 & Manga & Borborema, SP & 2009 \\
\hline $\mathrm{MN}-50$ & Manga & Jaú, SP & 2009 \\
\hline MN-51 & Manga & Jaboticabal, SP & 2009 \\
\hline $\mathrm{MN}-52$ & Manga & Borborema, SP & 2009 \\
\hline $\mathrm{MN}-53$ & Manga & Bauru, SP & 2009 \\
\hline $\mathrm{MN}-54$ & Manga & Bauru, SP & 2009 \\
\hline $\mathrm{MN}-55$ & Manga & Monte Alto, SP & 2009 \\
\hline $\mathrm{MN}-56$ & Manga & Magda, SP & 2009 \\
\hline $\mathrm{MN}-57$ & Manga & Cabrália Paulista, SP & 2009 \\
\hline MN-58 & Manga & Botucatu, SP & 2009 \\
\hline PS-59 & Maracujá & Adamantina, SP & 2007 \\
\hline PS-60 & Maracujá & Bauru, SP & 2010 \\
\hline PS-61 & Maracujá & Jaú, SP & 2007 \\
\hline PS-62 & Maracujá & Valinhos, SP & 2007 \\
\hline PS-63 & Maracujá & Bariri, SP & 2007 \\
\hline PS-64 & Maracujá & Campinas, SP & 2007 \\
\hline PS-65 & Maracujá & Campinas, SP & 2007 \\
\hline PS-66 & Maracujá & Irapuru, $\mathrm{SP}$ & 2007 \\
\hline PS-67 & Maracujá & Valinhos, SP & 2007 \\
\hline PS-68 & Maracujá & Irapuru, SP & 2007 \\
\hline PS-69 & Maracujá & Adamantina, SP & 2007 \\
\hline PS-70 & Maracujá & Pacaembu, SP & 2007 \\
\hline PS-71 & Maracujá & Bauru, SP & 2007 \\
\hline PE-72 & Pêssego & Paranapanema, SP & 2010 \\
\hline PE-73 & Pêssego & Paranapanema, SP & 2010 \\
\hline PE-74 & Pêssego & Botucatu, SP & 2010 \\
\hline PE-75 & Pêssego & Botucatu, SP & 2010 \\
\hline PE-76 & Pêssego & Botucatu, SP & 2010 \\
\hline PE-77 & Pêssego & Botucatu, SP & 2010 \\
\hline PE-78 & Pêssego & Marília, SP & 2010 \\
\hline PE-79 & Pêssego & Marília, SP & 2010 \\
\hline PE-80 & Pêssego & Marília, SP & 2010 \\
\hline PE-81 & Pêssego & Pindorama, SP & 2010 \\
\hline PE-82 & Pêssego & Bauru, SP & 2010 \\
\hline PE-83 & Pêssego & Bauru, SP & 2010 \\
\hline PE-84 & Pêssego & Paranapanema, SP & 2010 \\
\hline PE-85 & Pêssego & Paranapanema, SP & 2010 \\
\hline PE-86 & Pêssego & Paranapanema, SP & 2010 \\
\hline PE-87 & Pêssego & Pindorama, SP & 2010 \\
\hline PE- 88 & Pêssego & Bauru, SP & 2010 \\
\hline PE-89 & Pêssego & Pindorama, SP & 2010 \\
\hline PE-90 & Pêssego & Pindorama, SP & 2010 \\
\hline PE-91 & Pêssego & Bauru, SP & 2010 \\
\hline PE-92 & Pêssego & Paranapanema, SP & 2010 \\
\hline PE-93 & Pêssego & Pindorama, SP & 2010 \\
\hline PE-94 & Pêssego & Paranapanema, SP & 2010 \\
\hline
\end{tabular}


Tabela 2. Sequências de nucleotídeos obtidas do GenBank de isolados representativos de espécies utilizadas na análise filogenética.

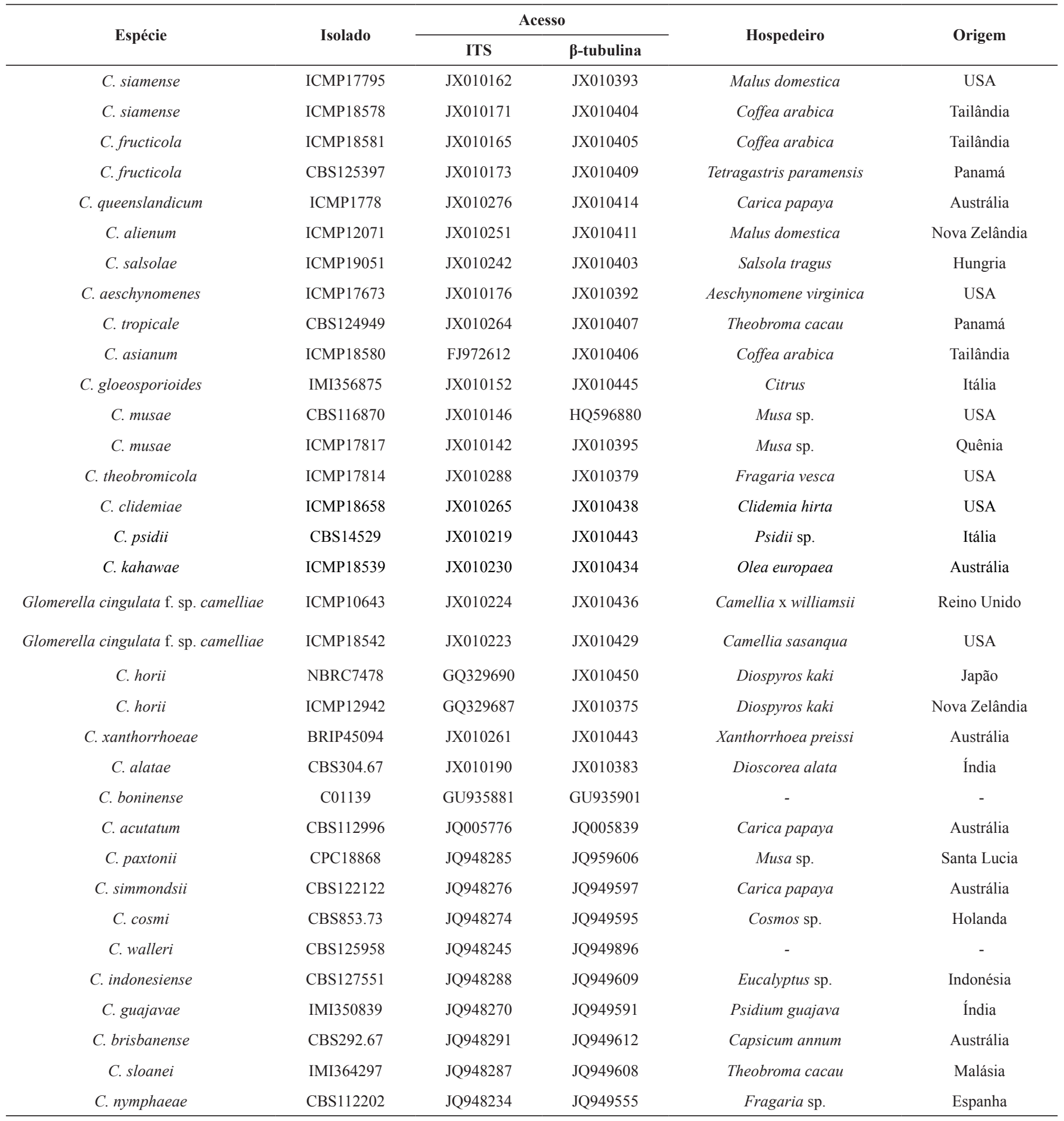

um único isolado (AV-22) produziu colônias com reverso cinza. Não foram detectados escleródios e setas nas colônias e $29 \%$ dos isolados produziram massas conidiais, de cor laranja (Tabela 3).

O maior desenvolvimento das colônias ocorreu a $25^{\circ} \mathrm{C}$, com exceção do isolado AV-09, que teve maior crescimento a $30^{\circ} \mathrm{C}$. Em todas as temperaturas, observou-se grande variabilidade entre isolados, independente do hospedeiro ou região de origem. A $25^{\circ} \mathrm{C}$, os isolados foram classificados em 13 grupos pelo teste de Scott-Knott a 5\% de probabilidade (Tabela 3). Menor desenvolvimento das colônias ocorreu quando incubadas a $35^{\circ} \mathrm{C}$. Entre os isolados de maracujá e pêssego, houve grande variabilidade no crescimento dos isolados a $35^{\circ} \mathrm{C}$. Em média, as colônias cultivadas a $35^{\circ} \mathrm{C}$ cresceram $62,4 \%$ menos que as incubadas a $25^{\circ} \mathrm{C}$ para os isolados de maracujá e $45,4 \%$ menos para os isolados de pêssego. Os isolados de abacate apresentaram menor variação na taxa de crescimento da colônia a $35^{\circ} \mathrm{C}$ e tiveram redução média de $52,9 \%$, quando comparadas às colônias incubadas a $25^{\circ} \mathrm{C}$. Os 
isolados de manga foram mais sensíveis ao aumento da temperatura de incubação e, em média, as colônias cultivadas a $35^{\circ} \mathrm{C}$ cresceram $78,9 \%$ menos que as colônias incubadas a $25^{\circ} \mathrm{C}$. Essa característica indica que os isolados de manga são distintos dos isolados das demais frutíferas, o que pode estar relacionado à especialização dos mesmos ao hospedeiro. Alta variabilidade cultural e presença de características comuns a mais de uma espécie ou complexo de espécies de Colletotrichum descritas na literatura $(15,25)$, como coloração das colônias e massa de esporos, impossibilitou a clara identificação específica dos isolados com base exclusivamente nas características avaliadas.

Todos os isolados de abacate, manga e maracujá e 14 isolados de pêssego (PE-72, PE-78, PE-79, PE-80, PE-81, PE-84, PE-85, PE-86, PE-87, PE-89, PE-90, PE-92, PE-93, PE-94) apresentaram predominância de conídios retos, hialinos, unicelulares, oblongos e com ápices arredondados (Figura 2), formato descrito com sendo característico das espécies do complexo C. gloeosporioides (25). O comprimento médio de conídios variou de 11,7 a 15,7 $\mu \mathrm{m}$ entre os isolados de abacate, de 11,4 a 15,1 $\mu \mathrm{m}$ entre os isolados de manga, de 12,2 a 14,8 $\mu \mathrm{m}$ entre os isolados de maracujá e de 10,5 a $13,1 \mu \mathrm{m}$ para os isolados de pessêgo. A largura média de conídios variou de 3,3 a 4,0 $\mu \mathrm{m}$ entre os isolados de abacate, de 2,9 a 4,1 $\mu \mathrm{m}$ para os isolados de manga, de 3,7 a 4,7 $\mu \mathrm{m}$ entre os isolados de maracujá e de 2,9 a 4,1 $\mu \mathrm{m}$ para os isolados de pêssego. Quanto às relações entre o comprimento e a largura dos conídios, observaram-se valores entre 3,3 e 4,3 para isolados de abacate, 3,2 e 4,7 para os isolados de manga, de 2,9 a 3,7 para os isolados de maracujá e de 3,1 a 4,5 para os isolados de pêssego.

Os demais isolados de pêssego (PE-73, PE-74, PE-75, PE-76, PE-77, PE-82, PE-83, PE-88 e PE-91) apresentaram predominância de conídios retos, hialinos, unicelulares, fusiformes, com ápices afilados (Figura 2), formato descrito como sendo característico para espécies do complexo C. acutatum (25). Esses isolados produziram conídios com comprimento médio entre 10,0 e 14,6 $\mu \mathrm{m}$, largura média entre 3,6 e 4,2 $\mu \mathrm{m}$ e relação entre o comprimento e largura de 2,8 a 3,8 (Tabela 3 ).

A morfometria dos conídios também não permitiu a identificação de espécies de Colletotrichum. Embora os formatos de conídios tenha permitido agrupar os isolados em dois grupos, sugerindo a existência de pelo menos duas espécies ou complexos de espécies, as dimensões dos conídios mostraram-se sobrepostas entre esses grupos, dificultando a interpretação dos resultados. Fato similar foi constatado por Andrade et al. (4), em estudo sobre a antracnose do mamoeiro, os quais verificaram que a maioria dos isolados apresentaram dimensões dentro da faixa em que há sobreposição entre $C$. gloeosporioides e C. acutatum impossibilitando a clara identificação das espécies.

\section{Caracterização molecular}

O par de oligonucleotídeos Cc1F1 e Cc2R1, específicos para o gênero Colletotrichum, amplificou um fragmento de DNA de $447 \mathrm{pb}$ para todos os isolados, confirmando que pertencem a esse gênero. O isolado padrão de C. acutatum e nove isolados de pêssego (PE-73, PE-74, PE-75, PE-76, PE-77, PE-82, PE-83, PE-88, PE-91), que apresentaram formato de conídios similar ao descrito para o complexo C. acutatum, tiveram fragmentos de DNA com $490 \mathrm{pb}$ amplificados com o uso do par de oligonucleotídeo CaInt2 e ITS4 (Tabela 4). O isolado padrão de C. gloeosporioides, todos os isolados de abacate, manga e 14 isolados de pêssego (PE72, PE-78, PE-79, PE-80, PE-81, PE-84, PE-85, PE-86, PE-87, PE-89, PE-90, PE-92, PE-93, PE-94) assim como três isolados de maracujá (PS-62, PS-66, PS-68), que apresentaram formato de conídios similar ao descrito para o complexo C. gloeosporioides, foram positivos em PCR com os oligonucleotídeos CgInt e ITS4, os quais amplificaram fragmentos de DNA com $450 \mathrm{pb}$. Nenhum isolado teve fragmentos de DNA amplificados em PCR utilizandose os oligonucleotídeos Col1/ITS4, exceto o isolado Man-76, utilizado como padrão positivo para esses oligonucleotídeos (2). Para 10 isolados, todos obtidos de maracujá (PS-59, PS-60, PS61, PS-63, PS-64, PS-65, PS-67, PS-69, PS-70, PS-71), não houve fragmentos de DNA amplificados pelos pares de oligonucleotídeos espécie-específicos utilizados nas PCRs.

A análise filogenética das sequências nucleotídicas concatenadas das regiões ITS e $\beta$-tubulina revelou que os isolados avaliados apresentam similaridades com isolados pertencentes às espécies dos complexos C. acutatum, C. gloeosporioides e C. boninense, cujas sequências foram obtidas no GenBank (Figura 3).

Todos os isolados de abacate e de manga compuseram clados com os isolados das espécies do complexo C. gloeosporioides, corroborando as análises morfo-culturais e por PCR. Para os isolados de abacate houve agrupamento entre AV-15 e C. siamense Prihast., L. Cai \& K.D. Hyde, entre AV-05 e C. fructicola Prihast., L. Cai \& K.D. Hyde, entre AV-22, AV-23 e C. queenslandicum B.S. Weir \& P.R. Johnst., entre AV-27 e C. alienum B.S. Weir \& P.R. Johnst. e entre AV-03 e C. gloeosporioides. Por sua vez, todos os isolados de manga (MN-45, MN-48, MN-51, MN-57, MN-58) agruparam no clado de $C$. asianum Prihast., L. Cai \& K.D. Hyde. Dos isolados de maracujá e pêssego identificados por características morfo-culturais e por PCR como sendo pertencentes ao complexo C. gloeosporioides, foram constatados agrupamentos dos isolados PS-68 e PE-93 com C. siamense, de PS-62 com $C$. queenslandicum e de PS-66 com C. asianum.

Os isolados de maracujá PS-59, PS-63 e PS-64, que não tiveram fragmentos de DNA amplificados por PCR com oligonucleotídeos específico, agruparam no clado com C. boninense (C01139), com alto suporte bootstrap.

Os isolados de pêssego PE-72 e PE-92 agruparam com isolados do complexo C. gloeosporioides e os isolados PE-73 e PE-74 agruparam com isolados do complexo C. acutatum, confirmando os resultados morfo-culturais e por PCR, porém, não compuseram clados com espécies específicas dentro desses complexos, indicando que esses isolados são geneticamente distintos das espécies avaliadas neste trabalho.

Analisando conjuntamente os resultados pode-se concluir que as características morfo-culturais e a identificação por PCR utilizando os oligonucleotídeos CgInt/ITS 4 e CaInt2/ITS4 são úteis como ferramentas complementares para identificação dos complexos de espécies C. gloeosporioides e C. acutatum, porém não são suficientes para identificação precisa das espécies do gênero Colletotrichum, assim como já reportado por outros autores $(7,15)$. De acordo com os resultados da caracterização morfo-cultural e da identificação molecular por PCR, apenas alguns isolados de pêssego puderam ser identificados como pertencentes ao complexo de espécies $C$. acutatum e a maioria dos isolados pode ser classificado no complexo de espécies $C$. gloeosporioides, que esteve associado à antracnose das quatro espécies frutíferas avaliadas. A espécie C. gloeosporioides é considerada por alguns autores como sendo o único agente causal da antracnose do abacate, manga e maracujá no Brasil (11, 19, 21). Entretanto, a análise filogenética das regiões ITS-5.8S rDNA e $\beta$-tubulina indicou que, no Estado de São Paulo, outras 
Tabela 3. Características culturais e morfológicas de isolados de Colletotrichum spp. obtidos de abacate, manga, maracujá e pêssego coletados no Estado de São Paulo.

\begin{tabular}{|c|c|c|c|c|c|c|c|c|c|c|c|c|c|c|c|c|c|c|c|c|c|c|c|c|c|}
\hline \multirow{3}{*}{$\begin{array}{l}\text { Isolado } \\
\mathrm{AV}-01\end{array}$} & \multicolumn{10}{|c|}{ Taxa de crescimento da colônia(mm/dia) } & \multirow{3}{*}{$\begin{array}{c}\text { Coloração da colônia } \\
\text { (superior/inferior) } \\
\text { ranca acinzentada / castanho }\end{array}$} & \multirow{3}{*}{$\begin{array}{c}\text { Massa } \\
\text { conidial }^{2} \\
-\end{array}$} & \multicolumn{9}{|c|}{ Dimensões dos conídios } & \multicolumn{4}{|c|}{$\begin{array}{l}\text { Formato dos } \\
\text { conídios }^{3}(\%)\end{array}$} \\
\hline & \multicolumn{2}{|c|}{$15^{\circ} \mathrm{C}$} & \multicolumn{2}{|c|}{$20^{\circ} \mathrm{C}$} & \multicolumn{2}{|c|}{$25^{\circ} \mathrm{C}$} & \multicolumn{2}{|c|}{$30^{\circ} \mathrm{C}$} & \multicolumn{2}{|c|}{$35^{\circ} \mathrm{C}$} & & & Com & uprin & mento $(\mu \mathrm{m})$ & & & n) & & & & 1 & 2 & 3 & 4 \\
\hline & 6,4 & $a^{1}$ & 8,5 & & 9,4 & $\mathrm{~h}$ & 9,1 & $\mathrm{e}$ & 5,7 & $\mathrm{e}$ & & & 13,4 & $\mathrm{c}$ & $(10,3-17,2)$ & 3,9 & $\mathrm{e}$ & $(2,9-4,8)$ & 3,5 & e & $(2,3-5,0)$ & 0 & 97 & 0 & 3 \\
\hline $\mathrm{AV}-02$ & 4,5 & $\mathrm{f}$ & 8,1 & & 12,3 & $\mathrm{~b}$ & 9,8 & $\mathrm{c}$ & 5,1 & 1 & branca acinzentada / castanho & - & 11,8 & $\mathrm{e}$ & $(9,5-14,3)$ & 3,5 & $\mathrm{~g}$ & $(2,9-4,0)$ & 3,4 & - & $(2,6-4,9)$ & 0 & 92 & 4 & 4 \\
\hline AV-03 & 5,3 & $\mathrm{c}$ & 8,5 & & 9,4 & $\mathrm{~h}$ & 8,6 & $\mathrm{f}$ & 5,3 & $f$ & cinza / castanho à cinza & + & 13,3 & $\mathrm{c}$ & $(11,0-15,4)$ & 4,0 & $\mathrm{~d}$ & $(3,7-4,4)$ & 3,4 & ( & $(2,5-4,2)$ & 0 & 87 & 5 & 8 \\
\hline $\mathrm{AV}-04$ & 4,7 & $\mathrm{e}$ & 6,9 & & 10,2 & $\mathrm{~g}$ & 7,9 & $\mathrm{~h}$ & 7,8 & $\mathrm{~b}$ & branca acinzentada / castanho & - & 12,3 & $\mathrm{e}$ & $(10,3-14,3)$ & 3,7 & $\mathrm{f}$ & $(3,3-5,1)$ & 3,3 & 1 & $(2,3-4,3)$ & 1 & 89 & 7 & 3 \\
\hline $\mathrm{AV}-05$ & 4,9 & $\mathrm{e}$ & 6,9 & & 12,3 & $\mathrm{~b}$ & 9,5 & $\mathrm{~d}$ & 7,9 & $\mathrm{~b}$ & cinza claro / castanho à cinza & + & 12,9 & $\mathrm{~d}$ & $(9,5-15,0)$ & 3,8 & $\mathrm{e}$ & $(2,9-4,4)$ & 3,4 & - & $(2,4-5,1)$ & 0 & 85 & 7 & 8 \\
\hline AV-06 & 5,3 & $\mathrm{c}$ & 8,3 & & 10,8 & $\mathrm{e}$ & 8,9 & $\mathrm{e}$ & 5,3 & $f$ & branca acinzentada / castanho & - & 13,1 & $\mathrm{c}$ & $(11,0-15,4)$ & 3,9 & $\mathrm{e}$ & $(3,3-4,8)$ & 3,4 & $c$ & $(2,5-4,7)$ & 0 & 96 & 2 & 2 \\
\hline AV-07 & 5,7 & $\mathrm{~b}$ & 7,9 & & 12,2 & $\mathrm{~b}$ & 9,8 & $\mathrm{c}$ & 5,0 & $\mathrm{f}$ & branca acinzentada / castanho & - & 12,2 & $\mathrm{e}$ & $(9,5-17,2)$ & 3,3 & $\mathrm{i}$ & $(2,9-4,0)$ & 3,7 & $\mathrm{~d}$ & $(2,4-5,3)$ & 0 & 87 & 5 & 8 \\
\hline $\mathrm{AV}-08$ & 5,8 & $\mathrm{~b}$ & 7,8 & & 10,4 & $\mathrm{f}$ & 7,8 & $\mathrm{~h}$ & 3,6 & $\mathrm{~h}$ & branca acinzentada / branca a salmão & + & 12,1 & $\mathrm{e}$ & $(10,3-14,3)$ & 3,7 & I & $(2,6-4,4)$ & 3,3 & 1 & $(2,5-4,6)$ & 0 & 76 & 6 & 18 \\
\hline AV-09 & 6,7 & $\mathrm{a}$ & 8,7 & & 9,4 & $\mathrm{~h}$ & 9,8 & $\mathrm{c}$ & 6,6 & $\mathrm{c}$ & branca acinzentada / castanho & - & 12,3 & $\mathrm{e}$ & $(9,5-17,2)$ & 3,5 & $\mathrm{~h}$ & $(2,6-5,5)$ & 3,6 & $\mathrm{~d}$ & $(2,3-5,6)$ & 0 & 89 & 7 & 4 \\
\hline $\mathrm{AV}-10$ & 4,3 & $\mathrm{f}$ & 8,5 & & 10,1 & $\mathrm{~g}$ & 8,6 & $\mathrm{f}$ & 4,0 & $\mathrm{~h}$ & branca acinzentada / castanho & - & 12,7 & $\mathrm{~d}$ & $(9,5-18,0)$ & 3,6 & $\mathrm{f}$ & $(2,9-5,1)$ & 3,5 & $\mathrm{e}$ & $(2,6-4,9)$ & 0 & 88 & 4 & 8 \\
\hline AV-11 & 5,8 & $\mathrm{~b}$ & 8,0 & & 10,8 & $\mathrm{e}$ & 8,6 & $\mathrm{f}$ & 2,6 & $\mathrm{i}$ & branca acinzentada / castanho & - & 11,7 & $\mathrm{f}$ & $(9,5-13,2)$ & 3,6 & $\mathrm{f}$ & $(2,9-4,4)$ & 3,3 & 1 & $(2,5-4,5)$ & 0 & 98 & 0 & 2 \\
\hline $\mathrm{AV}-12$ & 4,2 & $\mathrm{f}$ & 7,7 & & 10,2 & $\mathrm{~g}$ & 8,4 & $\mathrm{f}$ & 3,5 & $\mathrm{~h}$ & cinza claro / castanho à cinza & - & 13,1 & $\mathrm{c}$ & $(8,8-15,4)$ & 3,8 & $\mathrm{e}$ & $(2,9-5,1)$ & 3,5 & 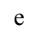 & $(2,4-4,2)$ & 0 & 79 & 6 & 15 \\
\hline $\mathrm{AV}-13$ & 4,5 & $\mathrm{f}$ & 8,1 & & 12,6 & $\mathrm{a}$ & 9,6 & $\mathrm{c}$ & 3,2 & $\mathrm{i}$ & cinza claro / castanho à cinza & + & 15,7 & $\mathrm{a}$ & $(12,5-19,1)$ & 3,7 & $\mathrm{f}$ & $(2,9-4,4)$ & 4,3 & $\mathrm{~b}$ & $(3,0-5,7)$ & 0 & 95 & 1 & 4 \\
\hline AV-14 & 5,7 & $\mathrm{~b}$ & 8,5 & & 9,7 & $\mathrm{~h}$ & 8,5 & $\mathrm{f}$ & 6,0 & d & branca acinzentada / salmão & + & 13,3 & $\mathrm{c}$ & $(11,0-15,4)$ & 3,6 & $\mathrm{f}$ & $(2,9-4,0)$ & 3,7 & 9 & $(3$, & 0 & 96 & 2 & 2 \\
\hline $\mathrm{AV}-15$ & 4,9 & $\mathrm{~d}$ & 7,8 & & 11,5 & $\mathrm{c}$ & 10,1 & $\mathrm{a}$ & 5,0 & $\mathrm{f}$ & branca acinzentada / castanho & - & 13,3 & $\mathrm{c}$ & $(11,0-15,0)$ & 3,7 & $\mathrm{f}$ & $(3,3-4,4)$ & 3,6 & $\mathrm{~d}$ & $(2,7-4,6)$ & 0 & 88 & 4 & 8 \\
\hline AV-16 & 5,1 & $\mathrm{~d}$ & 9,1 & & 11,6 & $\mathrm{c}$ & 10,1 & $\mathrm{a}$ & 4,1 & $\mathrm{~h}$ & cinza claro / castanho à cinza & + & 12,7 & $\mathrm{~d}$ & $(9,5-16,5)$ & 3,8 & $\mathrm{e}$ & $(2,9-4,8)$ & 3,3 & $\mathrm{f}$ & $(2,6-4,5)$ & 0 & 97 & 0 & 3 \\
\hline $\mathrm{AV}-17$ & 3,5 & $\mathrm{i}$ & 6,0 & & 8,2 & $\mathrm{j}$ & 6,5 & $\mathrm{k}$ & 6,9 & $\mathrm{c}$ & cinza claro / salmão & + & 11,9 & $\mathrm{e}$ & $(9,5-14,3)$ & 3,6 & $\mathrm{~g}$ & $(2,6-4,0)$ & 3,3 & $\mathrm{f}$ & $(2,4-$ & 0 & 89 & 5 & 6 \\
\hline AV-18 & 4,5 & $\mathrm{f}$ & 8,8 & & 11,6 & $\mathrm{c}$ & 9,3 & $\mathrm{~d}$ & 2,0 & $\mathrm{j}$ & branca acinzentada / castanho & - & 13,4 & $\mathrm{c}$ & $(9,5-15,4)$ & 3,7 & $\mathrm{f}$ & $(3,3-4,4)$ & 3,6 & $d$ & $(2,6-4$ & 0 & 95 & 2 & 3 \\
\hline AV-19 & 3,7 & $\mathrm{~h}$ & 4,4 & & 10,4 & $\mathrm{f}$ & 9,9 & $\mathrm{~b}$ & 6,2 & $\mathrm{~d}$ & branca acinzentada / castanho & - & 12,3 & $\mathrm{e}$ & $(10,3-14,3)$ & 3,6 & $\mathrm{~g}$ & $(2,9-4,4)$ & 3,5 & $\mathrm{e}$ & $(2,5-4,3)$ & 0 & 96 & 0 & 4 \\
\hline $\mathrm{AV}-20$ & 4,5 & $\mathrm{f}$ & 8,0 & & 11,6 & $\mathrm{c}$ & 9,3 & $\mathrm{~d}$ & 5,8 & $\mathrm{e}$ & branca acinzentada / castanho & - & 12,8 & $\mathrm{~d}$ & $(10,3-19,8)$ & 3,3 & $\mathrm{i}$ & $(2,6-5,5)$ & 3,8 & $\mathrm{c}$ & $(3,1-4,9)$ & 0 & 88 & 5 & 7 \\
\hline $\mathrm{AV}-21$ & 5,6 & $\mathrm{~b}$ & 8,2 & & 12,2 & $\mathrm{~b}$ & 10,2 & $\mathrm{a}$ & 7,0 & $\mathrm{c}$ & cinza claro / castanho à cinza & + & 14,2 & $\mathrm{~b}$ & $(11,7-17,2)$ & 3,5 & $\mathrm{~h}$ & $(2,9-4,0)$ & 4,1 & $\mathrm{c}$ & $(3,1-5,3)$ & 0 & 96 & 0 & 4 \\
\hline $\mathrm{AV}-22$ & 4,6 & $\mathrm{f}$ & 7,3 & & 11,2 & $\mathrm{~d}$ & 10,0 & $\mathrm{~b}$ & 5,6 & $\mathrm{e}$ & cinza / cinza & + & 12,6 & $\mathrm{~d}$ & $(9,5-15,0)$ & 3,6 & $\mathrm{~g}$ & $(2,9-4,0)$ & 3,5 & $\mathrm{e}$ & $(2,6-4,6)$ & 0 & 89 & 5 & 6 \\
\hline AV-23 & 5,2 & $\mathrm{c}$ & 8,5 & & 12,3 & $\mathrm{~b}$ & 8,3 & $\mathrm{~g}$ & 5,1 & $\mathrm{f}$ & cinza / castanho à cinza & - & 12,0 & $\mathrm{e}$ & $(9,5-15,4)$ & 3,6 & $\mathrm{~g}$ & $(2,9-4,4)$ & 3,4 & $\mathrm{e}$ & $(2,6-4,9)$ & 0 & 94 & 0 & 6 \\
\hline $\mathrm{AV}-24$ & 3,7 & $\mathrm{~h}$ & 6,0 & & 8,2 & $\mathrm{j}$ & 8,1 & $\mathrm{~g}$ & 3,4 & $\mathrm{~h}$ & branca acinzentada / castanho & - & 13,5 & $\mathrm{c}$ & $(11,0-16,5)$ & 3,9 & $\mathrm{e}$ & $(3,7-5,1)$ & 3,5 & $\mathrm{e}$ & $(2,5-4,5)$ & 0 & 98 & 0 & 2 \\
\hline $\mathrm{AV}-25$ & 4,2 & $\mathrm{f}$ & 7,1 & & 10,2 & $\mathrm{~g}$ & 9,4 & $\mathrm{~d}$ & 5,3 & $\mathrm{f}$ & branca acinzentada / castanho & - & 13,1 & $\mathrm{c}$ & $(10,3-17,2)$ & 3,7 & $\mathrm{f}$ & $(2,9-5,1)$ & 3,6 & $\mathrm{a}$ & $(2,5-4,9)$ & 0 & 77 & 8 & 15 \\
\hline AV-26 & 5,0 & $\mathrm{~d}$ & 8,9 & & 12,8 & $\mathrm{a}$ & 10,3 & $\mathrm{a}$ & 4,5 & $\mathrm{~g}$ & branca acinzentada / castanho & - & 13,2 & $\mathrm{c}$ & $(11,0-18,0)$ & 3,4 & $\mathrm{~h}$ & $(2,6-4,4)$ & 3,9 & $\mathrm{c}$ & $(2,5-4,9)$ & 0 & 90 & 4 & 6 \\
\hline AV-27 & 5,9 & $\mathrm{~b}$ & 8,5 & & 11,1 & $\mathrm{~d}$ & 8,6 & $\mathrm{f}$ & 6,2 & $\mathrm{~d}$ & branca acinzentada / castanho & - & 14,0 & $\mathrm{~b}$ & $(11,0-16,5)$ & 3,8 & $\mathrm{e}$ & $(3,7-4$ &, 7 & d & $(2,5-4$ & 0 & 94 & 2 & 4 \\
\hline AV-28 & 5,4 & $\mathrm{c}$ & 8,0 & & 12,7 & $\mathrm{a}$ & 9,5 & $\mathrm{~d}$ & 7,1 & 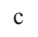 & branca acinzentada / castanho & - & 13,2 & $\mathrm{c}$ & $(10,3-17,2)$ & 3,8 & $\mathrm{e}$ & $(2,9-4,8)$ & 3,5 & C & $(2,5-5,6)$ & 0 & 98 & 0 & 2 \\
\hline AV-29 & 3,7 & $\mathrm{~h}$ & 6,5 & & 9,3 & $\mathrm{~h}$ & 7,0 & $\mathrm{i}$ & 5,6 & 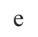 & 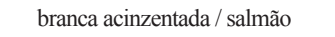 & + & 14,5 & $\mathrm{~b}$ & $(11,0-18,0)$ & 3,7 & $\mathrm{f}$ & $(2,9-4,4)$ & 4,0 & $\mathrm{c}$ & (3,0-3 & 0 & 90 & 0 & 0 \\
\hline $\mathrm{AV}-30$ & 5,1 & $\mathrm{~d}$ & 7,5 & & 11,3 & $\mathrm{~d}$ & 10,3 & $\mathrm{a}$ & 2,2 & $\mathrm{~J}$ & cinza / castanho à cinza & - & 13,2 & $\mathrm{c}$ & $(10,3-17,2)$ & 3,7 & $\mathrm{f}$ & $(2,9-4,0)$ & 5,0 & a & $(2,8-4,7)$ & 0 & 94 & 1 & 5 \\
\hline $\mathrm{MN}-31$ & 4,8 & $\mathrm{e}$ & 7,8 & & 9,0 & $\mathrm{i}$ & 7,1 & $\mathrm{i}$ & 1,8 & $\mathrm{j}$ & branca acinzentada / castanho & - & 14,2 & $\mathrm{~b}$ & $(11,0-18,3)$ & 3,8 & $\mathrm{e}$ & $(2,9-4,8)$ & 3,8 & $\mathrm{c}$ & $(2,5-$ & 3 & 84 & 6 & 7 \\
\hline $\mathrm{MN}-32$ & 3,6 & $\mathrm{i}$ & 6,8 & & 9,6 & $\mathrm{~h}$ & 8,6 & $\mathrm{f}$ & 1,6 & $\mathrm{k}$ & cinza claro / castanho à cinza & 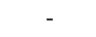 & 15,0 & $\mathrm{a}$ & $(12,5-17,6)$ & 3,9 & $\mathrm{e}$ & $(2,9-4,4)$ & 3,9 & $\mathrm{c}$ & $(2,8-$ & 0 & 95 & 3 & 2 \\
\hline $\mathrm{MN}-33$ & 3,4 & $\mathrm{i}$ & 7,2 & & 11,4 & $\mathrm{~d}$ & 8,0 & $\mathrm{~g}$ & 1,8 & $\mathrm{j}$ & branca acinzentada / castanho & - & 13,2 & $\mathrm{c}$ & $(10,3-15,4)$ & 4,1 & $\mathrm{~d}$ & $(3,3-4,4)$ & 3,3 & $\mathrm{f}$ & $(2$, & 3 & 86 & 5 & 6 \\
\hline $\mathrm{MN}-34$ & 3,3 & $\mathrm{i}$ & 5,4 & $\mathrm{i}$ & 7,0 & 1 & 6,1 & 1 & 1,7 & $\mathrm{k}$ & branca acinzentada / castanho & - & 14,2 & $\mathrm{~b}$ & $(11,7-16,9)$ & 3,7 & $\mathrm{f}$ & $(3,3-4,8)$ & 3,8 & $\mathrm{c}$ & $(2,7-4,9)$ & 0 & 93 & 3 & 4 \\
\hline $\mathrm{MN}-35$ & 5,1 & $\mathrm{~d}$ & 8,0 & & 12,4 & $\mathrm{~b}$ & 8,1 & $\mathrm{~g}$ & 1,6 & $\mathrm{k}$ & branca acinzentada / castanho & - & 13,3 & $\mathrm{c}$ & $(10,3-16,9)$ & 3,7 & $\mathrm{f}$ & $(2,9-5,1)$ & 3,7 & $\mathrm{~d}$ & $(2,6$ & 2 & 89 & 6 & 3 \\
\hline MN-36 & 4,1 & g & 6,6 & $\mathrm{~g}$ & 10,2 & $\mathrm{~g}$ & 8,1 & $\mathrm{~g}$ & 1,6 & $\mathrm{k}$ & branca acinzentada / castanho & - & 14,9 & $\mathrm{a}$ & $(11,0-19,8)$ & 3,6 & $\mathrm{~g}$ & $(2,9-4,8)$ & 4,3 & $\mathrm{~b}$ & $(2,8-6,4)$ & 0 & 90 & 3 & 7 \\
\hline $\mathrm{MN}-37$ & 2,8 & $\mathrm{j}$ & 6,4 & & 10,0 & $\mathrm{~g}$ & 7,1 & $\mathrm{i}$ & 1,5 & $\mathrm{k}$ & branca acinzentada / castanho & - & 12,4 & $\mathrm{~d}$ & $(9,5-18,3)$ & 3,0 & 1 & $(2,2-4,8)$ & 4,2 & b & $(2,2-6,0)$ & 0 & 96 & 3 & 1 \\
\hline MN-38 & 3,1 & $\mathrm{j}$ & 7,4 & & 10,0 & $\mathrm{~g}$ & 8,5 & $\mathrm{f}$ & 2,2 & $\mathrm{j}$ & cinza claro / castanho à cinza & - & 13,1 & $\mathrm{c}$ & $(10,3-18,7)$ & 3,7 & $\mathrm{f}$ & $(2,9-4,4)$ & 3,6 & $\mathrm{a}$ & $(2,7-5,7)$ & 0 & 97 & 3 & 0 \\
\hline MN-39 & 4,1 & $\mathrm{~g}$ & 8,0 & $\mathrm{c}$ & 9,8 & $\mathrm{~h}$ & 7,0 & $\mathrm{i}$ & 1,8 & $\mathrm{j}$ & branca acinzentada / castanho & - & 12,3 & $\mathrm{e}$ & $(9,5-15,4)$ & 3,7 & $\mathrm{f}$ & $(2,9-4,4)$ & 3,4 & e & $(2,5-4,2)$ & 0 & 83 & 11 & 6 \\
\hline $\mathrm{MN}-40$ & 4,7 & $\mathrm{e}$ & 7,1 & & 9,4 & $\mathrm{~h}$ & 8,7 & $\mathrm{f}$ & 2,0 & $\mathrm{~J}$ & cinza claro / castanho à cinza & - & 15,1 & $\mathrm{a}$ & $(12,5-18,3)$ & 3,4 & $\mathrm{~h}$ & & 4,5 & $\mathrm{a}$ & & 0 & 91 & 6 & 3 \\
\hline MN-41 & 3,9 & $\mathrm{~g}$ & 8,4 & $\mathrm{~b}$ & 12,6 & $\mathrm{a}$ & 7,9 & $\mathrm{~h}$ & 1,4 & $\mathrm{~K}$ & branca acinzentada / castanho & - & 14,5 & $\mathrm{~b}$ & $(11,0-16,9)$ & 3,7 & $\mathrm{f}$ & $(3,3-4,4)$ & 3,9 & $\mathrm{c}$ & $(2,7-4,7)$ & 0 & 90 & 6 & 4 \\
\hline $\mathrm{MN}-42$ & 3,9 & $\mathrm{~g}$ & 7,1 & $\mathrm{e}$ & 11,2 & $\mathrm{~d}$ & 7,1 & $\mathrm{i}$ & 1,8 & $\mathrm{~J}$ & branca acinzentada / castanho & + & 14,7 & $\mathrm{a}$ & $(11,7-19,8)$ & 3,6 & $\mathrm{~g}$ & $(2,9-4,4)$ & 4,3 & $\mathrm{~b}$ & $(2,7-6$ & 0 & 91 & 4 & 5 \\
\hline MN-43 & 4,1 & $\mathrm{~g}$ & 6,5 & $\mathrm{~g}$ & 10,0 & $\mathrm{~g}$ & 6,7 & $\mathrm{k}$ & 1,7 & $\mathrm{~K}$ & branca acinzentada / castanho & - & 12,8 & $\mathrm{~d}$ & $(8,8-16,1)$ & 3,3 & $\mathrm{i}$ & $(2,9-4,4)$ & 4,0 & $\mathrm{c}$ & $(2,4-5,5)$ & 0 & 93 & 2 & 5 \\
\hline $\mathrm{MN}-45$ & 3,3 & $\mathrm{i}$ & 4,7 & $\mathrm{j}$ & 9,0 & $\mathrm{i}$ & 6,2 & 1 & 1,6 & $\mathrm{k}$ & ho & - & 14,4 & $\mathrm{~b}$ & $(10,3-19,8)$ & 3,1 & $\mathrm{j}$ & $-3,7)$ & 4,7 & $\mathrm{a}$ & ,8) & 0 & 87 & 7 & 6 \\
\hline MN-46 & 2,8 & $\mathrm{j}$ & 5,9 & $\mathrm{~h}$ & 8,3 & $\mathrm{j}$ & 6,4 & $\mathrm{k}$ & 1,7 & $\mathbf{n}$ & cinza claro / castanho à cinza & + & 11,4 & $\mathrm{f}$ & $(8,8-16,1)$ & 2,9 & 1 & $(2,6-3,7)$ & 3,9 & $\mathrm{c}$ & $(2,4-5,5)$ & 0 & 93 & 4 & 3 \\
\hline MN-47 & 2,9 & $\mathrm{j}$ & 5,4 & $\mathrm{i}$ & 9,1 & $\mathrm{i}$ & 5,3 & $\mathrm{n}$ & 1,7 & $\mathbf{K}$ & inza claro / castanho à cinza & - & 14,0 & b & $(11,0-18,7)$ & 3,5 & $\mathrm{~h}$ & $(2,9-4,4)$ & 4,0 & $\mathrm{c}$ & $(2,8-6,4)$ & 0 & 91 & 4 & 5 \\
\hline $\mathrm{MN}-48$ & 3,7 & $\mathrm{~h}$ & 6,9 & $\mathrm{f}$ & 9,4 & $\mathrm{~h}$ & 6,8 & $\mathrm{j}$ & 1,4 & $\mathrm{k}$ & branca acinzentada / castanho & - & 13,5 & $\mathrm{c}$ & $(9,5-16,9)$ & 3,2 & $\mathrm{i}$ & $(2,9-3,7)$ & 4,2 & $\mathrm{~b}$ & $(3,3-5,8)$ & 0 & 92 & 3 & 5 \\
\hline MN-49 & 3,9 & $\mathrm{~g}$ & 7,3 & $\mathrm{e}$ & 9,7 & $\mathrm{~h}$ & 6,0 & $\mathrm{~m}$ & 1,2 & K & branca acinzentada / castanho & - & 12,1 & $\mathrm{e}$ & $(10,3-15,8)$ & 3,4 & $\mathrm{~h}$ & $(2,6-4,4)$ & 3,6 & $\mathrm{~d}$ & $(2,5-5,4)$ & 0 & 96 & 4 & 0 \\
\hline
\end{tabular}


Tabela 3. Características culturais e morfológicas de isolados de Colletotrichum spp. obtidos de abacate, manga, maracujá e pêssego coletados no Estado de São Paulo.

\begin{tabular}{|c|c|c|c|c|c|c|c|c|c|c|c|c|c|c|c|c|c|c|c|c|c|c|c|c|c|}
\hline \multirow{3}{*}{$\begin{array}{l}\text { Isolado } \\
\mathrm{MN}-50\end{array}$} & \multicolumn{10}{|c|}{ Taxa de crescimento da colônia(mm/dia) } & \multirow{3}{*}{$\begin{array}{l}\text { Coloração da colônia } \\
\text { (superior/inferior) } \\
\text { nza claro / castanho à cinza }\end{array}$} & \multirow{3}{*}{$\begin{array}{c}\text { Massa } \\
\text { conidial }^{2} \\
-\end{array}$} & \multicolumn{9}{|c|}{ Dimensões dos conídios } & \multicolumn{4}{|c|}{$\begin{array}{l}\text { Formato dos } \\
\operatorname{conídios}^{3}(\%)\end{array}$} \\
\hline & \multicolumn{2}{|c|}{$15^{\circ} \mathrm{C}$} & \multicolumn{2}{|c|}{$20^{\circ} \mathrm{C}$} & \multicolumn{2}{|c|}{$25^{\circ} \mathrm{C}$} & \multicolumn{2}{|c|}{$30^{\circ} \mathrm{C}$} & \multicolumn{2}{|c|}{$35^{\circ} \mathrm{C}$} & & & \multicolumn{3}{|c|}{ Comprimento $(\mu \mathrm{m})$} & & rgu & $\mathrm{ra}(\mu \mathrm{m})$ & & III & Larg. & 1 & 2 & 3 & 4 \\
\hline & 4,0 & $\mathrm{~g}$ & 6,3 & $\mathrm{~h}$ & 10,1 & $\mathrm{~g}$ & 8,5 & $\mathrm{f}$ & 1,9 & $\mathrm{j}$ & & & 13,3 & $\mathrm{c}$ & $(11,7-14,7)$ & 3,3 & $\mathrm{i}$ & $(2,6-4,0)$ & 4,1 & $\mathrm{c}$ & $(2,9-5,7)$ & 1 & 87 & 6 & 6 \\
\hline $\mathrm{MN}-51$ & 4,4 & $\mathrm{f}$ & 8,1 & & 11,3 & $\mathrm{~d}$ & 5,8 & $\mathrm{~m}$ & 2,5 & $\mathrm{i}$ & branca acinzentada / castanho & - & 11,7 & $\mathrm{f}$ & $(8,8-14,7)$ & 3,7 & $\mathrm{f}$ & $(2,9-4,4)$ & 3,2 & $\mathrm{f}$ & $(2,4-4,5)$ & 0 & 93 & T & 3 \\
\hline MN-52 & 3,7 & $\mathrm{~h}$ & 6,9 & $\mathrm{f}$ & 11,2 & $\mathrm{~d}$ & 8,2 & $\mathrm{~g}$ & 6,1 & $\mathrm{~d}$ & cinza claro / castanho à cinza & - & 14,0 & $\mathrm{~b}$ & $(11,7-16,1)$ & 3,9 & $\mathrm{e}$ & $(3,3-4,8)$ & 3,6 & $\mathrm{~d}$ & $(2,8-4,4)$ & 0 & 95 & 2 & 3 \\
\hline $\mathrm{MN}-53$ & 4,3 & $\mathrm{f}$ & 7,5 & $\mathrm{e}$ & 10,4 & $\mathrm{f}$ & 8,0 & $\mathrm{~g}$ & 2,2 & $\mathrm{j}$ & branca acinzentada / castanho & - & 14,9 & $\mathrm{a}$ & $(11,7-19,8)$ & 3,5 & $\mathrm{~h}$ & $(2,9-4,4)$ & 4,3 & $\mathrm{~b}$ & $(2,7-5,6)$ & 0 & 91 & 4 & 5 \\
\hline $\mathrm{MN}-54$ & 4,2 & $\mathrm{f}$ & 7,4 & $\mathrm{e}$ & 10,8 & $\mathrm{e}$ & 9,6 & $\mathrm{c}$ & 2,3 & $\mathrm{j}$ & cinza claro / castanho à cinza & - & 11,7 & $\mathrm{f}$ & $(8,8-14,7)$ & 3,1 & $\mathrm{j}$ & $(2,6-4,0)$ & 3,7 & $\mathrm{~d}$ & $(2,6-4,9)$ & 0 & 88 & 5 & 7 \\
\hline $\mathrm{MN}-55$ & 5,6 & $\mathrm{~b}$ & 6,9 & $\mathrm{f}$ & 10,6 & $\mathrm{f}$ & 8,9 & $\mathrm{e}$ & 4,7 & $\mathrm{~g}$ & branca acinzentada / castanho & - & 11,4 & $\mathrm{f}$ & $(8,8-16,1)$ & 3,6 & $\mathrm{~g}$ & $(2,6-4,0)$ & 3,3 & $\mathrm{f}$ & $(2,4-4,6)$ & 0 & 93 & 3 & 4 \\
\hline $\mathrm{MN}-56$ & 4,4 & $\mathrm{f}$ & 8,3 & $\mathrm{~b}$ & 10,1 & $\mathrm{~g}$ & 7,2 & $\mathrm{i}$ & 3,2 & $\mathrm{i}$ & branca acinzentada / castanho & - & 11,8 & $\mathrm{e}$ & $(9,5-15,4)$ & 3,2 & $\mathrm{i}$ & $(2,6-4,4)$ & 3,7 & $\mathrm{~d}$ & $(2,5-6,0)$ & 0 & 92 & 4 & 4 \\
\hline $\mathrm{MN}-57$ & 3,7 & $\mathrm{i}$ & 6,5 & & 7,9 & $\mathrm{k}$ & 6,2 & 1 & 1,9 & $\mathrm{j}$ & cinza / castanho à cinza & + & 11,9 & $\mathrm{e}$ & $(8,8-13,6)$ & 3,4 & $\mathrm{~h}$ & $(2,9-4,4)$ & 3,6 & $\mathrm{~d}$ & $(2,4$ & 0 & 85 & 7 & 8 \\
\hline $\mathrm{MN}-58$ & 3,1 & $\mathrm{j}$ & 7,5 & $\mathrm{e}$ & 10,0 & $\mathrm{~g}$ & 6,5 & $\mathrm{k}$ & 2,1 & $\mathrm{j}$ & branca acinzentada / castanho & - & 14,9 & a & $(11,0-19,8)$ & 3,3 & $\mathrm{i}$ & $(2,9-4,0)$ & 4,6 & a & $(3,1-$ & 0 & 89 & 3 & 8 \\
\hline PS-59 & 3,2 & $\mathrm{j}$ & 4,2 & $\mathrm{k}$ & 6,5 & $\mathrm{~m}$ & 4,6 & $\mathrm{p}$ & 1,3 & $\mathrm{k}$ & branca acinzentada / salmão & - & 14,1 & $\mathrm{~b}$ & $(11,7-16,9)$ & 4,4 & $\mathrm{~b}$ & $(3,7-5,1)$ & 3,2 & $\mathrm{f}$ & $(2,7-4,2)$ & 0 & 87 & 3 & 10 \\
\hline PS-60 & 4,5 & $\mathrm{f}$ & 4,7 & $\mathrm{j}$ & 8,2 & $\mathrm{j}$ & 6,8 & $\mathrm{j}$ & 3,0 & $\mathrm{i}$ & cinza claro / castanho à cinza & - & 13,5 & $\mathrm{c}$ & $(11,7-16,1)$ & 4,3 & $\mathrm{c}$ & $(3,7-5,1)$ & 3,2 & $\mathrm{f}$ & $(2,3-4,0)$ & 0 & 97 & 2 & 1 \\
\hline PS-61 & 3,0 & $\mathrm{j}$ & 4,7 & $\mathrm{j}$ & 6,5 & $\mathrm{~m}$ & 5,2 & o & 2,7 & $\mathrm{i}$ & branca acinzentada / salmão & - & 14,1 & $\mathrm{~b}$ & $(11,7-16,9)$ & 4,2 & $\mathrm{c}$ & $(3,7-4,8)$ & 3,3 & $\mathrm{f}$ & $(2,7-4,2)$ & 0 & 98 & 2 & 0 \\
\hline PS-62 & 4,0 & $\mathrm{~g}$ & 7,6 & $\mathrm{e}$ & 11,9 & $\mathrm{c}$ & 10,0 & $\mathrm{~b}$ & 4,6 & $\mathrm{~g}$ & cinza claro / castanho à cinza & - & 13,8 & $\mathrm{c}$ & $(12,1-16,5)$ & 4,0 & $\mathrm{~d}$ & $(3,3-4,4)$ & 3,5 & e & $(2,8-4,1)$ & 0 & 95 & 3 & 2 \\
\hline PS-63 & 3,8 & $\mathrm{~h}$ & 4,9 & $\mathrm{j}$ & 6,9 & 1 & 5,4 & $\mathrm{n}$ & 2,8 & $\mathrm{i}$ & branca acinzentada / salmão & - & 14,4 & $\mathrm{~b}$ & $(12,5-16,9)$ & 4,7 & $\mathrm{a}$ & $(4,0-5,1)$ & 3,1 & $\mathrm{~g}$ & $(2,6-3,8)$ & 0 & 98 & 2 & 0 \\
\hline PS-64 & 4,3 & $\mathrm{f}$ & 6,6 & $\mathrm{~g}$ & 11,0 & $\mathrm{e}$ & 7,6 & $\mathrm{~h}$ & 2,7 & $\mathrm{i}$ & branca acinzentada / salmão & - & 14,8 & $\mathrm{a}$ & $(12,5-18,0)$ & 4,7 & $\mathrm{a}$ & $(4,0-5,5)$ & 3,1 & $\mathrm{~g}$ & $(2,5-3,8)$ & 0 & 97 & 2 & 1 \\
\hline PS-65 & 3,0 & $\mathrm{j}$ & 4,5 & $\mathrm{j}$ & 7,2 & 1 & 6,6 & $\mathrm{k}$ & 1,5 & $\mathrm{k}$ & branca acinzentada / castanho & - & 12,6 & $\mathrm{~d}$ & $(10,3-14,3)$ & 4,4 & $\mathrm{~b}$ & $(3,7-4,8)$ & 2,9 & $\mathrm{~h}$ & & 0 & 96 & 3 & 1 \\
\hline PS-66 & 4,4 & $\mathrm{f}$ & 7,4 & $\mathrm{e}$ & 12,5 & $\mathrm{a}$ & 10,2 & $\mathrm{a}$ & 7,3 & $\mathrm{c}$ & cinza claro / castanho à cinza & - & 13,1 & c & $(9,9-15,8)$ & 3,7 & $\mathrm{f}$ & $(3,3-4,0)$ & 3,6 & d & $(2,7-4,8)$ & 0 & 93 & 4 & 3 \\
\hline PS-67 & 3,9 & $\mathrm{~g}$ & 5,6 & $\mathrm{i}$ & 7,9 & $\mathrm{k}$ & 6,0 & $\mathrm{~m}$ & 3,0 & $\mathrm{i}$ & branca acinzentada / salmão & - & 13,9 & $\mathrm{~b}$ & $(11,7-18,3)$ & 4,4 & $\mathrm{~b}$ & $(4,0-5,1)$ & 3,2 & $\mathrm{f}$ & $(2,5-4,2)$ & 0 & 95 & 3 & 2 \\
\hline PS-68 & 3,4 & $\mathrm{i}$ & 6,4 & $\mathrm{~g}$ & 12,3 & $\mathrm{~b}$ & 9,7 & $\mathrm{c}$ & 5,5 & $\mathrm{e}$ & cinza claro / castanho à cinza & - & 14,1 & $\mathrm{~b}$ & $12,8-15,8)$ & 3,8 & $\mathrm{e}$ & $(3,3-4,4)$ & 3,7 & d & $(2,9-4$ & 0 & 96 & 3 & 1 \\
\hline PS-69 & 3,5 & $\mathrm{i}$ & 4,9 & $\mathrm{j}$ & 7,3 & 1 & 5,5 & $\mathrm{n}$ & 1,7 & $\mathrm{k}$ & ão & - & 12,2 & $\mathrm{e}$ & $(9,9-13,6)$ & 4,2 & $\mathrm{c}$ & $(3,7-4,8)$ & 2,9 & $\mathrm{~h}$ & $(2,5-3$ & 0 & 91 & 5 & 4 \\
\hline PS-70 & 3,6 & $\mathrm{i}$ & 4,9 & $\mathrm{j}$ & 7,0 & 1 & 5,0 & o & 2,8 & $\mathrm{i}$ & branca acinzentada / salmão & - & 14,8 & a & $(13,2-16,1)$ & 4,1 & $\mathrm{~d}$ & $(3$, & 3,7 & d & $(2$ & 0 & 90 & 7 & 3 \\
\hline PS-71 & 3,6 & $\mathrm{i}$ & 5,6 & $\mathrm{i}$ & 7,7 & $\mathrm{k}$ & 7,7 & $\mathrm{~h}$ & 3,6 & $\mathrm{~h}$ & cinza claro / castanho à cinza & - & 13,4 & $\mathrm{c}$ & $(12,1-16,5)$ & 4,1 & $\mathrm{~d}$ & $(3,3-4,4)$ & 3,3 & f & $(2,8-4$ & 0 & 92 & 6 & 2 \\
\hline PE-72 & 4,7 & $\mathrm{e}$ & 7,7 & $\mathrm{~d}$ & 10,7 & $\mathrm{e}$ & 9,8 & $\mathrm{c}$ & 7,0 & $\mathrm{c}$ & cinza / castanho à cinza & + & 10,9 & $\mathrm{f}$ & $(7,0-14,3)$ & 3,3 & $\mathrm{i}$ & $(2,2-3,3)$ & 3,4 & $\mathrm{e}$ & $(2,1-5,6)$ & 0 & 90 & 5 & 5 \\
\hline PE-73 & 2,8 & $\mathrm{j}$ & 5,8 & $\mathrm{~h}$ & 6,8 & $\mathrm{~m}$ & 5,9 & $\mathrm{~m}$ & 2,3 & $\mathrm{j}$ & branca acinzentada a rosa / salmão & + & 14,6 & $\mathrm{~b}$ & $(12,1-16,9)$ & 3,8 & $\mathrm{e}$ & $(3,3-4,8)$ & 3,8 & $\mathrm{c}$ & $(3,0-5,1)$ & 71 & 20 & 8 & 1 \\
\hline PE-74 & 2,0 & $\mathrm{k}$ & 3,8 & 1 & 7,2 & 1 & 5,9 & $\mathrm{~m}$ & 1,4 & $\mathrm{k}$ & branca acinzentada / castanho & + & 11,1 & $\mathrm{f}$ & $(8,8-16,9)$ & 3,9 & $\mathrm{e}$ & $(2,9-4,8)$ & 2,9 & $\mathrm{~h}$ & $(2,2-5,1)$ & 77 & 16 & 7 & 0 \\
\hline PE-75 & 1,9 & $\mathrm{k}$ & 3,8 & 1 & 6,4 & $\mathrm{~m}$ & 4,7 & $\mathrm{p}$ & 1,4 & $\mathrm{k}$ & cinza / castanho à cinza & + & 12,4 & $\mathrm{~d}$ & $(10,3-15,0)$ & 3,9 & $\mathrm{e}$ & $(3,3-4,8)$ & 3,2 & $\mathrm{f}$ & $(2,5-4,1)$ & 65 & 26 & 9 & 0 \\
\hline PE-76 & 2,0 & $\mathrm{k}$ & 3,9 & 1 & 7,2 & 1 & 5,6 & $\mathrm{n}$ & 1,5 & $\mathrm{k}$ & branca acinzentada / castanho & + & 13,7 & c & $(11,4-15,8)$ & 4,2 & $\mathrm{c}$ & $(3,3-5,1)$ & 3,3 & $\mathrm{f}$ & $(2,2-4,3)$ & 80 & 14 & 5 & 1 \\
\hline PE-77 & 2,0 & $\mathrm{k}$ & 4,0 & 1 & 7,3 & 1 & 5,8 & $\mathrm{~m}$ & 1,7 & $\mathrm{k}$ & branca acinzentada / castanho & + & 12,3 & e & $(9,5-15,0)$ & 4,1 & $\mathrm{~d}$ & $(3,3-5,1)$ & 3,1 & $\mathrm{~g}$ & $(2,4-4,1)$ & 73 & 16 & 9 & 2 \\
\hline PE-78 & 2,9 & $\mathrm{j}$ & 5,3 & $\mathrm{i}$ & 11,0 & $\mathrm{e}$ & 8,8 & $\mathrm{e}$ & 7,4 & $\mathrm{c}$ & ho & - & 12,7 & $\mathrm{~d}$ & $10,3-14,3)$ & 3,9 & $\mathrm{e}$ & & 3,3 & $\mathrm{f}$ & & 0 & 95 & 3 & 2 \\
\hline PE-79 & 3,3 & $\mathrm{i}$ & 5,6 & $\mathrm{i}$ & 10,4 & $\mathrm{f}$ & 8,5 & $\mathrm{f}$ & 7,8 & $\mathrm{~b}$ & a clara & 1 & 12,3 & e & & 3,0 & 1 & & 4,3 & $\mathrm{~b}$ & & 0 & 94 & 4 & 2 \\
\hline PE-80 & 3,1 & $\mathrm{j}$ & 5,5 & $\mathrm{i}$ & 11,0 & $\mathrm{e}$ & 9,6 & $\mathrm{c}$ & 8,0 & $\mathrm{~b}$ & (2) & - & 12,5 & $\mathrm{~d}$ & & 2,9 & 1 & & 4,5 & $\mathrm{a}$ & & 0 & 86 & 1 & 7 \\
\hline PE-81 & 2,3 & $\mathrm{k}$ & 5,0 & $\mathrm{j}$ & 11,8 & $\mathrm{c}$ & 7,3 & $\mathrm{i}$ & 8,7 & $\mathrm{a}$ & cinza / castanho à cinza & + & 13,1 & c & $1,0-15,8)$ & 3,9 & $\mathrm{e}$ & & 3,4 & e & $(2,4-$ & 0 & 96 & 2 & 2 \\
\hline PE-82 & 3,3 & $\mathrm{i}$ & 4,9 & $\mathrm{j}$ & 8,1 & $\mathrm{j}$ & 5,4 & $\mathrm{n}$ & 1,1 & $\mathrm{k}$ & cinza / castanho à cinza & + & 12,7 & $\mathrm{~d}$ & $(11,4-15,0)$ & 4,2 & $\mathrm{c}$ & $(3,3-5,5)$ & 3,1 & $\mathrm{~g}$ & $(2,2-3,9)$ & 76 & 19 & 5 & 0 \\
\hline PE-83 & 3,5 & $\mathrm{i}$ & 4,7 & $\mathrm{j}$ & 7,4 & 1 & 5,4 & $\mathrm{n}$ & 1,3 & $\mathrm{k}$ & nza clara / castanno a cinza & 1 & 10,0 & g & $(0,1-1 J, 7)$ & 2,0 & $\mathrm{f}$ & $(2,9-4,0)$ & 2,0 & $\mathrm{~h}$ & $(2,1-J, 1)$ & 85 & 12 & 0 & 0 \\
\hline PE-84 & 3,8 & $\mathrm{~h}$ & 6,5 & $\mathrm{~g}$ & 10,6 & $\mathrm{f}$ & 8,3 & $\mathrm{~g}$ & 7,8 & $\mathrm{~b}$ & Cinza / castantio a cinza & - & 12,7 & $\mathrm{~d}$ & $(11,0-16,5)$ & 2,4 & $\mathrm{~h}$ & $(2,9-4,0)$ & 3,0 & $\mathrm{c}$ & $(2,7-J, 0)$ & 0 & 97 & 2 & 1 \\
\hline PE-85 & 4,2 & $\mathrm{f}$ & 6,5 & $\mathrm{~g}$ & 11,9 & $\mathrm{~b}$ & 9,7 & $\mathrm{c}$ & 7,2 & $\mathrm{c}$ & inza clara / castanho à cinza & - & 11,1 & $\mathrm{f}$ & $(8,4-14,3)$ & 3,4 & $\mathrm{~h}$ & $(2,2-4,4)$ & 3,4 & $\mathrm{e}$ & $(2,1-5,8)$ & 0 & 90 & 4 & 6 \\
\hline 86 & 4,3 & $\mathrm{f}$ & 5,9 & $\mathrm{~h}$ & 11,0 & e & 9,2 & d & 7,4 & $\mathrm{c}$ & atode & - & 12,1 & $\mathrm{e}$ & $(8,4-16,5)$ & 3,6 & $\mathrm{~g}$ & $(2,2-4,0)$ & 3 & e & $(2,1-7$ & 0 & 93 & 3 & 4 \\
\hline PE-87 & 5,1 & d & 7,2 & $\mathrm{e}$ & 11,0 & e & 10,2 & $\mathrm{a}$ & 7,2 & $\mathrm{c}$ & ceosinzentode / cocto & - & 12,2 & e & $88-150)$ & 3,6 & $\mathrm{~g}$ & $(2,6-4,8)$ & 5 & $\mathrm{e}$ & 9) & 0 & 95 & 2 & 3 \\
\hline PE-88 & 3,3 & $\mathrm{i}$ & 4,9 & $\mathrm{j}$ & 6,8 & $\mathrm{~m}$ & 5,0 & o & 1,0 & $\mathrm{k}$ & to & 1 & 13,3 & $\mathrm{c}$ & $11,0-15,0)$ & 3,9 & $\mathrm{e}$ & $(3,3-4,8)$ & 3,4 & $\mathrm{e}$ & 4) & 87 & 11 & 2 & 0 \\
\hline PE-89 & 2,9 & $\mathrm{j}$ & 7,6 & $\mathrm{e}$ & 10,8 & e & 8,6 & f & 9,2 & $\mathrm{a}$ & anca acinzentada / castanho & + & 12,6 & d & $8,8-15,0)$ & 4,1 & $\mathrm{~d}$ & $(3,7-4,8)$ & 3,1 & $\mathrm{~g}$ & $(1,8-$ & 0 & 88 & 5 & 7 \\
\hline PE-90 & 3,0 & $\mathrm{j}$ & 6,1 & $\mathrm{~h}$ & 11,7 & $\mathrm{c}$ & 9,7 & $\mathrm{c}$ & 9,2 & $\mathrm{a}$ & cinza clara / castanho à cinza & + & 11,4 & $\mathrm{f}$ & $(8,4-13,6)$ & 3,7 & $\mathrm{f}$ & & 3,2 & $\mathrm{f}$ & $(1,9-5,3)$ & 2 & 83 & 7 & 8 \\
\hline PE-91 & 3,5 & $\mathrm{i}$ & 5,2 & $\mathrm{i}$ & 6,9 & 1 & 4,2 & $\mathrm{p}$ & 1,1 & $\mathrm{k}$ & cinza / castanho à cinza & + & 11,2 & $\mathrm{f}$ & $(9,2-14,3)$ & 3,7 & $\mathrm{f}$ & $(2,9-4,8)$ & 3,1 & $\mathrm{~g}$ & ,3) & 70 & 17 & 11 & 2 \\
\hline PE-92 & 3,5 & $\mathrm{i}$ & 6,7 & $\mathrm{~g}$ & 9,4 & $\mathrm{~h}$ & 9,3 & d & 6,4 & d & branca acinzentada / castanho & - & 12,2 & e & $(8,4-15,0)$ & 3,6 & $\mathrm{~g}$ & $(2,2-4,4)$ & 3,4 & $\mathrm{e}$ & $(2,2-4,9)$ & 0 & 91 & 4 & 5 \\
\hline PE-93 & 4,0 & g & 5,6 & $\mathrm{i}$ & 11,0 & $\mathrm{e}$ & 8,6 & $\mathrm{f}$ & 7,5 & $\mathrm{~b}$ & cinza clara / castanho à cinza & - & 10,5 & g & $(7,7-13,6)$ & 3,1 & $\mathrm{j}$ & $(2,2-3,7)$ & 3,4 & $\mathrm{e}$ & $(2,3-4,7)$ & 0 & 89 & 5 & 6 \\
\hline PE-94 & 4,3 & $\mathrm{f}$ & 6,7 & $\mathrm{~g}$ & 12,1 & $\mathrm{~b}$ & 9,1 & $\mathrm{e}$ & 5,7 & $\mathrm{e}$ & cinza clara / castanho à cinza & - & 12,8 & $\mathrm{~d}$ & $(8,8-15,0)$ & 3,6 & $\mathrm{~g}$ & $(2,6-4,0)$ & 3,7 & $\mathrm{~d}$ & $(2,2-5,9)$ & 0 & 92 & 5 & 3 \\
\hline C.V. $(\%)^{4}$ & 5,6 & & 4,0 & & 3,9 & & 3,5 & & 11,1 & & & & 12 & & & 11,2 & & & 10,0 & & & & & & \\
\hline
\end{tabular}

${ }^{1}$ Médias seguidas de letras distintas na coluna diferem entre si pelo teste de Scott-Knott ao nível de 5\% de probabilidade.

${ }^{2}(+)$ estrutura presente, $(-)$ estrutura ausente.

${ }^{3}$ Formato: (1) reto, fusiforme, com ápices afilados; (2) reto, oblongo, com ápices arredondados; (3) reto, clavado, afilado em uma extremidade e redondo na outra; (4) reto, com constrição. ${ }^{4}$ Coeficiente de variação. 


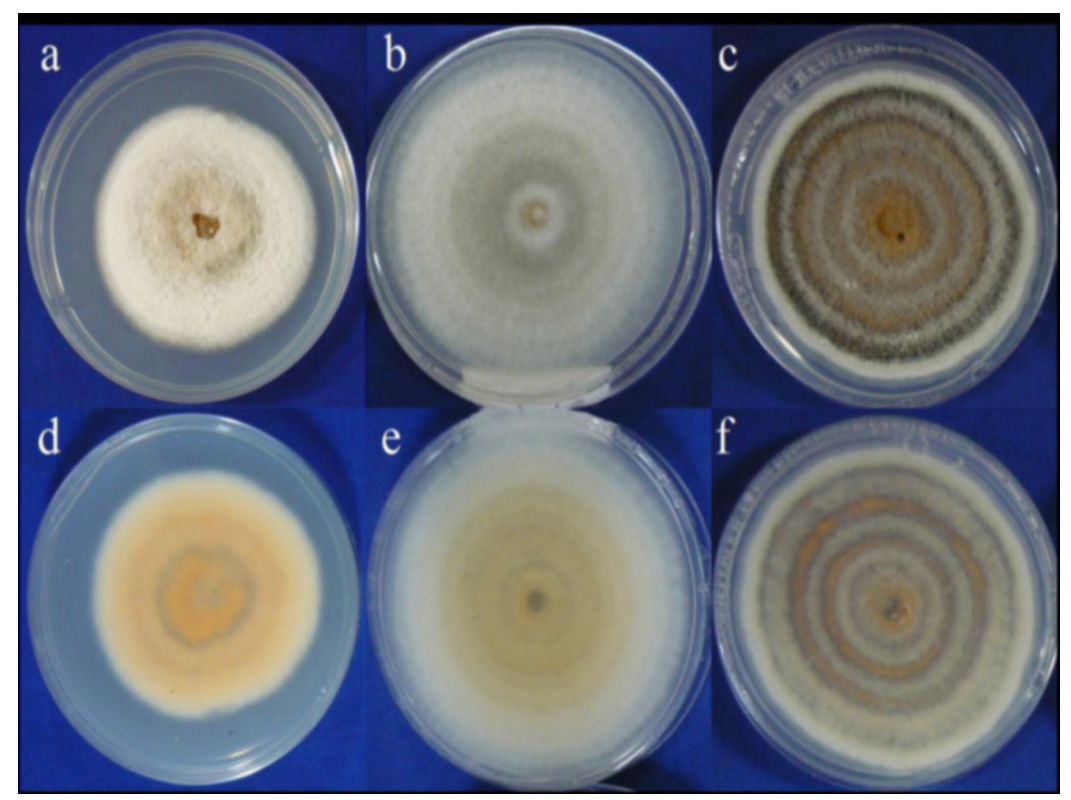

Figura 1. Aspectos de colônias de diferentes isolados de Colletotrichum spp., cultivadas a $25^{\circ} \mathrm{C} \mathrm{em} \mathrm{meio} \mathrm{BDA:} \mathrm{Colônia} \mathrm{branca} \mathrm{acinzentada} \mathrm{no} \mathrm{centro} \mathrm{com} \mathrm{reverso}$ salmão e com massa conidial laranja no centro $(\mathrm{a}, \mathrm{d})$, colônia cinza clara com reverso castanho (b,e), colônia cinza com reverso cinza e massas conidiais laranja em anéis concêntricos $(\mathrm{c}, \mathrm{f})$.
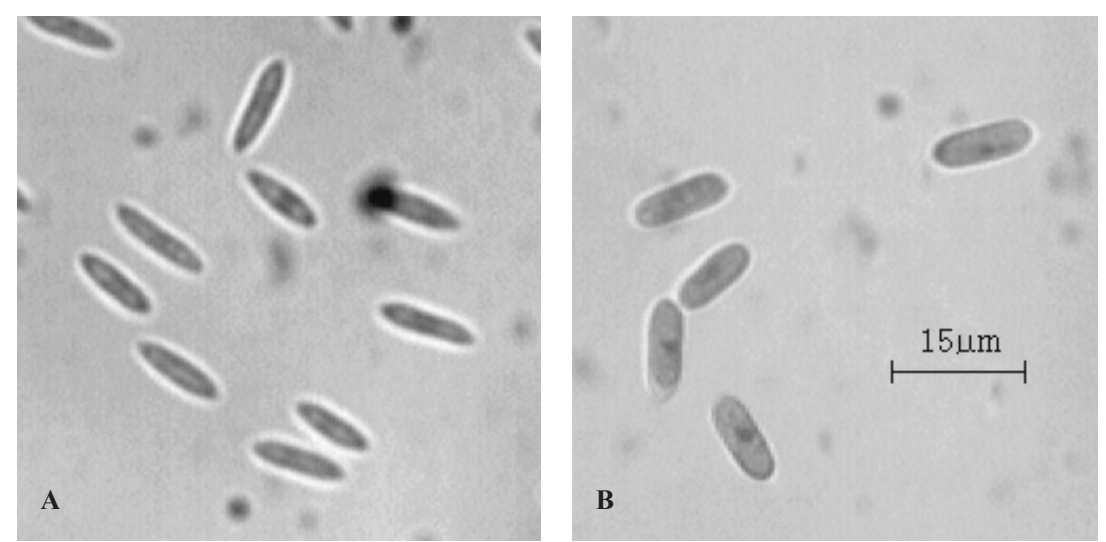

Figura 2. Conídios produzidos por isolados de Colletotrichum: (a) retos, hialinos, unicelulares, fusiformes, com ápices afilados (PE-88); (b) retos, hialinos, unicelulares, oblongos e com ápices arredondados (AV-30).

espécies do complexo Colletotrichum gloeosporioides também podem causar antracnose nessas frutíferas. A análise filogenética revelou, ainda, que três isolados de maracujá (PS-59, PS-63 e PS-64), escolhidos entre 10 isolados que não foram amplificados por PCR com oligonucleotídeos espécie-específicos, pertencem a espécie $C$. boninense, já constatada causando antracnose em maracujá no Brasil (27). Adicionalmente, a análise filogenética demonstrou a presença de isolados de pêssego que não agruparam com os isolados das espécies dos complexos C. gloeosporioides e C. acutatum, indicando a necessidade de realização de trabalhos complementares para a identificação específica dos isolados causadores da antracnose do pêssego.

Os resultados deste trabalho demonstram a existência de variabilidade fenotípica e genética entre isolados causadores de antracnose em frutíferas no Estado de São Paulo, permitindo melhor compreensão sobre a etiologia da antracnose do abacate, manga, maracujá e pêssego regionalmente. Essa constatação é útil para subsidiar o desenvolvimento e adoção de medidas de controle específicas para as espécies causadoras de antracnose no Estado, sejam essas medidas de natureza genética, química ou cultural. 


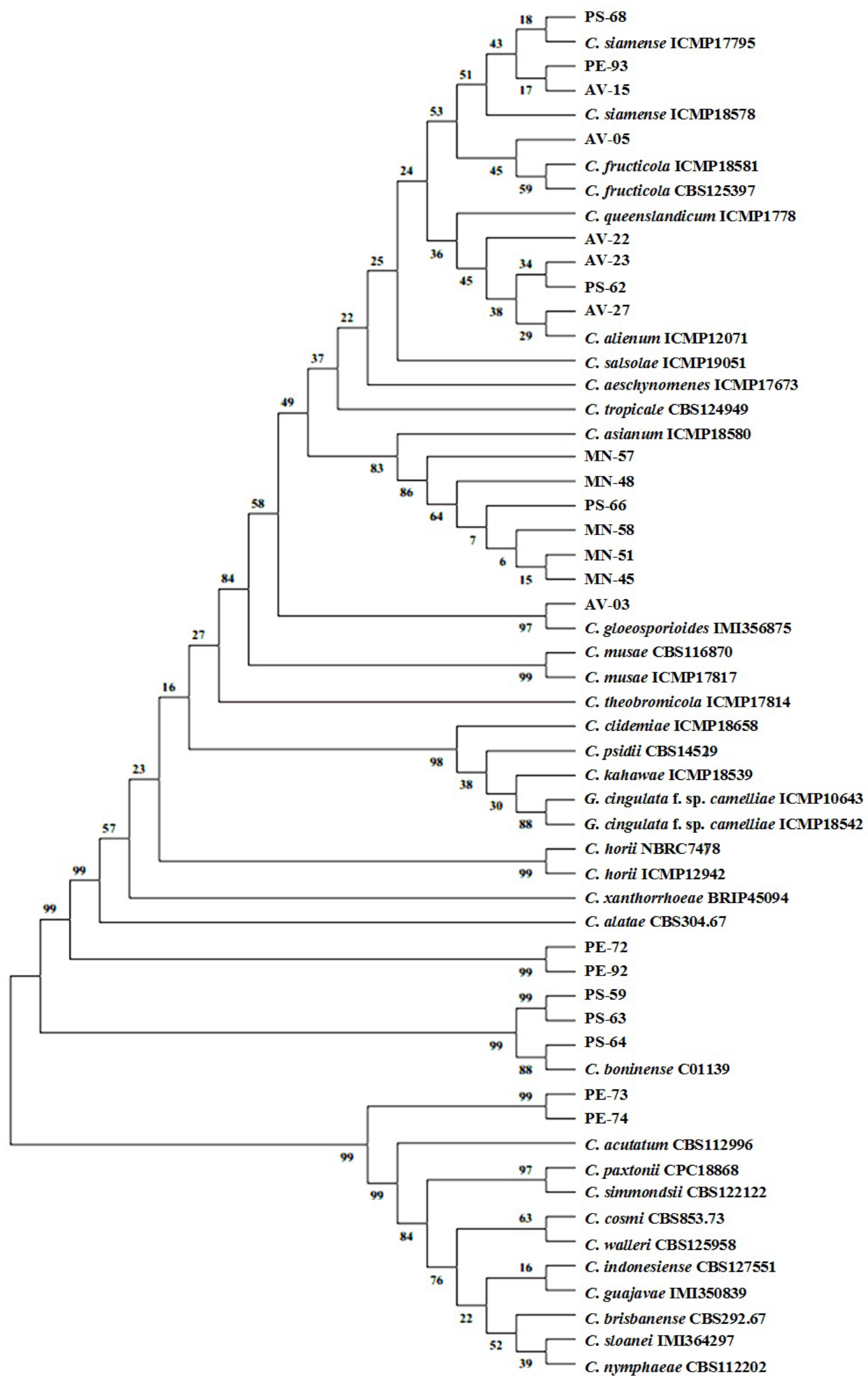

Figura 3. Árvore filogenética construída pelo método Neighbor-Joining com sequências concatenadas de genes das regiões ITS-5.8S rDNA e $\beta$-tubulina de isolados de Colletotrichum spp (bootstrap com 10.000 replicações). 
Tabela 4. Identificação de isolados de Colletotrichum obtidos de abacate, manga, maracujá e pêssego em reação em cadeia da polimerase (PCR) utilizando oligonucleotídeos espécie-específicos.

\begin{tabular}{|c|c|c|c|c|c|c|c|}
\hline \multirow{3}{*}{ Isolado } & \multicolumn{3}{|c|}{ Oligonucleotídeos* } & \multirow{3}{*}{ Isolado } & \multicolumn{3}{|c|}{ Oligonucleotídeos* } \\
\hline & CgInt & CaInt2 & Col1 & & CgInt & CaInt2 & Col1 \\
\hline & ITS4 & ITS4 & ITS4 & & ITS4 & ITS4 & ITS4 \\
\hline AVO-33-4B & + & - & - & MN-47 & + & - & - \\
\hline TUT-137 & - & + & - & MN-48 & + & - & - \\
\hline Man-16 & - & - & + & MN-49 & + & - & - \\
\hline AV-01 & + & - & - & $\mathrm{MN}-50$ & + & - & - \\
\hline $\mathrm{AV}-02$ & + & - & - & MN-51 & + & - & - \\
\hline $\mathrm{AV}-03$ & + & - & - & $\mathrm{MN}-52$ & + & - & - \\
\hline $\mathrm{AV}-04$ & + & - & - & MN-53 & + & - & - \\
\hline $\mathrm{AV}-05$ & + & - & - & $\mathrm{MN}-54$ & + & - & - \\
\hline $\mathrm{AV}-06$ & + & - & - & $\mathrm{MN}-55$ & + & - & - \\
\hline $\mathrm{AV}-07$ & + & - & - & MN-56 & + & - & - \\
\hline $\mathrm{AV}-08$ & + & - & - & MN-57 & + & - & - \\
\hline AV-09 & + & - & - & MN-58 & + & - & - \\
\hline AV-10 & + & - & - & PS-59 & - & - & - \\
\hline AV-11 & + & - & - & PS-60 & - & - & - \\
\hline $\mathrm{AV}-12$ & + & - & - & PS-61 & - & - & - \\
\hline AV-13 & + & - & - & PS-62 & + & - & - \\
\hline AV-14 & + & - & - & PS-63 & - & - & - \\
\hline AV-15 & + & - & - & PS-64 & - & - & - \\
\hline AV-16 & + & - & - & PS-65 & - & - & - \\
\hline AV-17 & + & - & - & PS-66 & + & - & - \\
\hline AV-18 & + & - & - & PS-67 & - & - & - \\
\hline AV-19 & + & - & - & PS-68 & + & - & - \\
\hline AV-20 & + & - & - & PS-69 & - & - & - \\
\hline $\mathrm{AV}-21$ & + & - & - & PS-70 & - & - & - \\
\hline AV-22 & + & - & - & PS-71 & - & - & - \\
\hline AV-23 & + & - & - & PE-72 & + & - & - \\
\hline AV-24 & + & - & - & PE-73 & - & + & - \\
\hline AV-25 & + & - & - & PE-74 & - & + & - \\
\hline AV-26 & + & - & - & PE-75 & - & + & - \\
\hline AV-27 & + & - & - & PE-76 & - & + & - \\
\hline AV-28 & + & - & - & PE-77 & - & + & - \\
\hline AV-29 & + & - & - & PE-78 & + & - & - \\
\hline AV-30 & + & - & - & PE-79 & + & - & - \\
\hline $\mathrm{MN}-31$ & + & - & - & PE-80 & + & - & - \\
\hline $\mathrm{MN}-32$ & + & - & - & PE-81 & + & - & - \\
\hline $\mathrm{MN}-33$ & + & - & - & PE-82 & - & + & - \\
\hline $\mathrm{MN}-34$ & + & - & - & PE-83 & - & + & - \\
\hline MN-35 & + & - & - & PE-84 & + & - & - \\
\hline MN-36 & + & - & - & PE-85 & + & - & - \\
\hline $\mathrm{MN}-37$ & + & - & - & PE-86 & + & - & - \\
\hline MN-38 & + & - & - & PE-87 & + & - & - \\
\hline MN-39 & + & - & - & PE-88 & - & + & - \\
\hline $\mathrm{MN}-40$ & + & - & - & PE-89 & + & - & - \\
\hline MN-41 & + & - & - & PE-90 & + & - & - \\
\hline $\mathrm{MN}-42$ & + & - & - & PE-91 & - & + & - \\
\hline $\mathrm{MN}-43$ & + & - & - & PE-92 & + & - & - \\
\hline $\mathrm{MN}-45$ & + & - & - & PE-93 & + & - & - \\
\hline MN-46 & + & - & - & PE-94 & + & - & - \\
\hline
\end{tabular}

*Presença (+) e ausência (-) de fragmento específico de DNA amplificado.

\section{REFERÊNCIAS BIBLIOGRÁFICAS}

1. Adaskaveg, J.E.; Hartin, R.J. Characterization of Colletotrichum acutatum isolates causing anthracnose of almond and peach in California. Phytopathology, Saint Paul, v.87, n.9, p.979-987, 1997.

2. Afanador-Kafuri, L.; Minz, D.; Maymon, M.; Freeman, S. Characterization of Colletotrichum isolates from tamarillo, passiflora and mango in Colombia and identification of a unique species from the genus. Phytopathology, Saint Paul, v.93, n.5, p.579-587, 2003.

3. Almeida, L.C.C.; Coêlho, R.S.B. Caracterização da agressividade de isolae dos de Colletotrichum de maracujá amarelo com marcadores bioquímico, fisiológico e molecular. Fitopatologia Brasileira, Brasília, v.32, n.4, p.318-328, 2007.

4. Andrade, E.M.; Uesugi, C.H.; Ueno, B.; Ferreira, M.A.S. V. Caracterização morfocultural e molecular de isolados de Colletotrichum gloeosporioides patogênicos ao mamoeiro. Fitopatologia Brasileira, Brasília, v.32, n.1, p.21-31, 2007.

5. Avila-Quezada, G.; Silva-Rojas, H.V.; Teliz-Ortiz, D. First report of the anamorph of Glomerella acutata causing anthracnose on avocado fruits in Mexico. Plant Disease, Saint Paul, v.91, p.1200-1200, 2007.

6. Bernstein, B.; Zehr, E.I.; Dean, R.A.; Shabi, E. Characteristics of Colletotrichum from peach, apple, pecan, and other hosts. Plant Disease, Saint Paul, v.79, n.5, p.478-482, 1995.

7. Cai, L.; Hyde, K.D.; Taylor, P.W.J.; Weir, B.S.; Waller, J.; Abang, M.M.; Zhang, J.Z.; Yang, Y.L.; Phoulivong, S.; Liu, Z.Y.; Prihastuti, H.; Shivas, R.G.; Mckenzie, E.H.C.; Johnston, P.R. A polyphasic approach for studying Colletotrichum. Fungal Diversity, Chiang Mai, v.39, p.183-204, 2009.

8. Cannon, P.F.; Damm, U; Johnston, P.R.; Weir, B.S. Colletotrichum status and future directions. Studies in Mycology, Utrecht, v.73, p.181-213, 2012.

9. Cullen, D.W.; Lees, A.K.; Toth, I.K.; Duncan, J.M. Detection of Colletotrichum coccodes from soil and potato tubers conventional and quantitative real-time PCR. Plant Pathology, Oxford, v.51, n.3, p.281-292, 2002.

10. Dean, R.; Van Kan, J.A.L.; Pretorius, Z.A.; Hammond-Kosack, K.E.; Di Pietro; A.; Spanu, P.D.; Rudd, J.J.; Dickman, M.; Kahmann, R.; Ellis, J.; Foster, G.D. The Top 10 fungal pathogens in molecular plant pathology. Molecular Plant Pathology, Malden, v.13, p.414430, 2012.

11. Fischer, I.H., Kimati, H., Resende, J.A.M. Doenças do maracujazeiro (Passiflora spp.). In: Kimati, H., Amorim, L., Resende, J.A.M., Bergamin Filho, A., Camargo, L.E.A. (Eds.) Manual de fitopatologia vol. 2: Doenças de plantas cultivadas. $4^{\circ}$ ed. São Paulo: Agronômica Ceres, 2005. p.467-474.

12. Fitzell, R.D. Colletotrichum acutatum as a cause of anthracnose of mango in New South Wales. Plant Disease Reporter, Washington, v.63, p.1067-1070, 1979.

13. Glass, N.L.; Donaldson, G.C. Development of primer sets designed for use with the PCR to amplify conserved genes from filamentous Ascomycetes. Applied and Environmental Microbiology, Washington, v.6, p.1323-1330, 1995.

14. Guerber, J.C.; Liu, B.; Correll, J.C.; Johnston, P.R. Characterization of diversity in Colletotrichum acutatum sensu lato by sequence analysis of two gene introns, mtDNA and intron RFLPs, and mating compatibility. Mycologia, Lancaster, v.95, n.5, p.872-895, 2003.

15. Menezes, M. Aspectos biológicos e taxonômicos de espécies do gênero Colletotrichum.Anais da Academia Pernambucana de Ciência Agronômica, Recife, v.3, p.170-179, 2006.

16. Mills, P.R.; Sreenivasaprasad, S.; Brown, A.E. Detection and differentiation of Colletotrichum gloeosporioides isolates using PCR. FEMS Microbiology Letters, Amsterdam, v.98, n.1/3, p.137-144, 1992.

17. Murray, M.G.; Thompson, W.S. Rapid isolation of high molecular weight DNA. Nucleic Acids Research, Oxford, v.8, p.4321-4325, 1980

18. Nei; M., Kumar, S. Molecular Evolution and Phylogenetics. New York: Oxford University Press, 2000. 333p.

19. Piccinin, E.; Pascholati, S.F.; Di Piero, R.M. Doenças Do Abacateiro. In: Kimati, H.; Amorim, L.; Rezende, J.A.M.; Bergamin Filho, A.; Camargo, L.E.A. (Ed.). Manual de fitopatologia. 4. ed.São Paulo: Ceres, 2005. v.2, cap.1, p.1-7. 
20. Pileggi, S. A. V.; Oliveira, S. F. V.; Andrade, C. W. ; Vicente, V.A. ; Dalzoto, P.R. ; Cruz, G. K. ; Gabardo, J. ; Massola Júnior,N.S. ; Tozze Júnior, H.J.; Kava-Cordeiro, V.; Galli-Terasawa, L. V.; Pimentel, I. C. ; Glienke, C.Molecular and morphological markers for rapid distinction between two Colletotrichum species. Canadian Journal of Microbiology (Print),Ottawa, v.55, p.1076-1088, 2009.

21. Pimenta, A.A. Caracterização morfométrica, patogênica e genética de isolados de Colletotrichum gloeosporioides, agente causal da antracnose em manga (Mangifera indica L.). 2009. 79 p.Dissertação (Mestrado em Agronomia) - Faculdade de Ciências Agrárias e Veterinárias, Universidade Estadual Paulista "Júlio de Mesquita Filho", Jaboticabal, 2009

22. Ploetz, R.C. Mango diseases caused by fungi: anthracnose. In: Ploetz, R.C.; Zentmeyer, G.A.; Nishijima, N.T.; Rohrbasch, K.G.; Ohr, H.D. (Ed.). Compendium of Tropical Fruit Diseases. Saint Paul: APS Press, 1994. p.35-36.

23. Silva-Rojas, H.V.; Avila-Quezada, G. Phylogenetic and morphologit cal identification of Colletotrichum boninense: a novel causal agent of anthracnose in avocado. Plant Pathology, Saint Paul, v.60, n.5, p.899-908, 2011.

24. Sreenivasaprasad, S.; Sharada, K.; Brown, A.E.; Mills, P.R. PCRbased detection of Colletotrichum acutatum on strawberry. Plant
Pathology, London, v.45, n.4, p.650-655, 1996.

25. Sutton, B.C. The genus Glomerella and its anamorph Colletotrichum. In: BAILEY, J.A.; JEGER, M.J. (Ed.). Colletotrichum: biology, pathology and control. Oxon: CAB International, 1992. p.1-26.

26. Tozze Júnior, H.J. Caracterização e identificação de espécies de Colletotrichum associadas à antracnose do pimentão (Capsicum annuum) no Brasil. 2007. 81 p.Dissertação (Mestrado em Fitopatologia) - Escola Superior de Agricultura "Luiz de Queiroz", Universidade de São Paulo, Piracicaba, 2006.

27. Tozze Júnior, H.J.; Fischer, I.H.; Câmara, M.P.S.; Massola Júnior, N.S. First report of Colletotrichum boninense infecting yellow passion fruit (Passiflora edulis f. flavicarpa) in Brazil. Australasian Plant Disease Notes, Orange, v.5, p.70-72, 2010.

28. Tozze Júnior, H.J.; Mello, M.B.A.; Massola Júnior, N.S. Caracterização morfológica e fisiológica de isolados de Colletotrichum sp. causadores de antracnose em solanáceas. Summa Phytopathologica, Botucatu, v.32, n.1, p.71-79, 2006.

29. White, T.J.; Bruns, T.; Lee, S.; Taylor, J. Ampflification and direct sequencing of fungal ribossomal RNA genes for phylogenetics. In: Innis M.A.; Gelfand, D.H.; Sninsky, J.J.; White, T.J. (Ed.) PCR Protocols: a guide to methods and applications. San Diego: Academic Press, 1990. p.315-322. 